The following manuscript is a preprint that has not undergone peer review. We submitted the manuscript for publication in a peer reviewed journal. Please note that subsequent versions of this manuscript may have different content. If accepted, the revised, peer-reviewed manuscript will be available on the EarthArxiv website, and can be accessed using the "Peer-reviewed Publication" DOI link on the right hand side of this page. The authors welcome constructive feedback. Please contact Latisha Brengman (lbrengma@d.umn.edu) with inquiries or suggestions.

\title{
Constraining mechanisms of quartz precipitation during silicification and chemical sedimentation in the in the $\sim 2.7$ Ga Abitibi Greenstone Belt, Canada
}

Latisha A. Brengman ${ }^{1,2 *}$, Christopher M. Fedo ${ }^{1}$, Martin J. Whitehouse ${ }^{3}$, Neil R. Banerjee ${ }^{4}$, Iffat Jabeen $^{4}$

${ }^{1}$ Department of Earth and Planetary Sciences, University of Tennessee, Knoxville, TN 37996, USA, ${ }^{2}$ Department of Earth and Environmental Sciences, University of Minnesota - Duluth, Duluth, MN, 55812 USA, ${ }^{3}$ Department of Geosciences, Swedish Museum of Natural History, Stockholm, Sweden, SE-105 05, ${ }^{4}$ Department of Earth Sciences, Western University, London, Ontario, Canada, N6A 5B7

Corresponding Author*: Latisha A. Brengman, Department of Earth and Environmental Sciences, University of Minnesota - Duluth, 1114 Kirby Drive, 221 Heller Hall, Duluth, MN, 55812, Phone: (218)-726-7586, Email: 1brengma@d.umn.edu

Keywords: silicification, iron formation, geochemistry, silicon isotopes, oxygen isotopes 
Silica-rich Precambrian rocks often preserve geochemical information and microfossil remnants from the early biosphere. Because these rocks are such critical geochemical and paleontological archives, we need robust tools to identify the chemical and physical conditions under which siliceous Precambrian rocks form, and determine how such information links to the specific depositional environment. Here, we investigate a series of sub- to greenschist facies Sirich Archean rocks from the $\sim 2.7$ Ga Abitibi Greenstone Belt, Canada that represent chemical sedimentary rocks and rocks formed via silica-addition through the process of silicification. We report data for major and trace element geochemistry, multi-crystal silicon and oxygen isotopes of quartz using isotope ratio mass spectrometry, and texture-specific silicon isotope values measured using secondary ion mass spectrometry on chemical sedimentary rocks, their silicified equivalents, and silicified volcanic rocks. We find that in such a well-preserved terrane where we can utilize petrographic textures and geochemical attributes to establish rock origin, we can also distinguish silicon isotope signatures of rocks that form via chemical sedimentation, from those that form via silicification. Though chemical sedimentary rocks display a wide range of silicon isotopes values $\left(\delta^{30} \mathrm{Si}_{\mathrm{NBS}-28}=-3.21 \pm 0.21 \%\right.$ to $0.52 \pm 0.40 \%$ o $)$ similar to modern, low-temperature quartz precipitates, silicified volcanic rocks often possess near igneous signatures $\left(\delta^{30} \mathrm{Si}_{\mathrm{NBS}-28}=-0.289\right.$ to $0.257 \pm 0.03 \%(2 \sigma)$ ), close to values measured for modern oceanic crust. Specifically, quartz phenocrysts away from silicified areas in volcanic rocks possess silicon isotope values $\left(\delta^{30} \mathrm{Si}_{\mathrm{NBS}}\right.$ ${ }_{28}=-0.58 \pm 0.23 \%$ o to $0.76 \pm 0.20 \%$ ) similar to both phenocrysts inside silicified areas $\left(\delta^{30} \mathrm{Si}_{\mathrm{NBS}}\right.$ ${ }_{28}=-0.81 \pm 0.18 \%$ to $0.27 \pm 0.17 \%$ ) and to micro-quartz crystals from silicified volcanic matrix material $\left(\delta^{30} \mathrm{Si}_{\mathrm{NBS}-28}=-1.06 \pm 0.22 \%\right.$ to $\left.0.16 \pm 0.20 \%\right)$ when considering error. We also find that we can explain some of the silicon isotope heterogeneity measured using high-spatial resolution techniques, by using targeted, texture-specific single crystal analysis of quartz within rocks with a well-established geologic context. Overall, we interpret that texturally linked micro-scale silicon isotope heterogeneity likely results from changing chemical and physical conditions during the precipitation of quartz within the sample.

\section{Introduction}

Multiple previous studies have discussed the silicon isotope composition of marine siliceous precipitates (chert and BIF) through time (André et al., 2006; van den Boorn et al., 2007; Abraham et al., 2011; van den Boorn et al., 2010; Heck et al., 2011; Steinhoefel et al., 2009; 2010; Chakrabarti et al., 2012; Delvigne et al., 2012; Marin-Carbonne and Chaussidon., 2012). Some have identified a perceived temporal trend in the compiled chert and iron formation archive, where silicon isotope values systematically become enriched in ${ }^{30} \mathrm{Si}$. Such a trend is typically explained by abiotic processes, including mixing of hydrothermal and continental silicon sources to the ocean (e.g. Heck et al., 2011) or a gradual cooling of ocean temperatures since the Archean (e.g., Robert and Chaussidon, 2006; Marin-Carbonne et al., 2012) due to the lack of evidence for silica utilizing organisms early in Earth history. In addition to the temporal trend, several studies (van den Boorn 2007; 2010; Abraham et al., 2011; Brengman et al., 2016) indicate a measurable silicon isotope difference between rocks formed via replacement processes (such as silicification during hydrothermalism) and rocks formed strictly from chemical sedimentation. Here, we focus on data from the $\sim 2.7 \mathrm{Ga}$ Abitibi Greenstone Belt to determine if the distinction between silicon isotopes of quartz within silicified volcanic rocks and associated chemical sedimentary rocks recognized 
by van den Boorn et al. (2007) and Abraham et al. (2011) exists at this locality, and how such differences may track mechanisms of quartz precipitation.

In this paper, we present geochemical and isotopic data from sub-greenschist to greenschist mechanisms of quartz precipitation within siliceous rocks formed via chemical sedimentation and replacement. The $\sim 2.7 \mathrm{Ga}$ Abitibi greenstone belt, Canada (AGB) represents a composite volcanic arc terrane with well-preserved, stratigraphically continuous successions of meta-volcanic and meta-sedimentary rocks (Mueller et al., 2009, Thurston et al., 2008; Mueller and Mortensen, 2002; Ayer et al., 2002; Mueller et al., 1996). Locally mineralized and hydrothermally altered volcanic suites within the belt are often characterized by excess silica due to post-formation addition of silica phases (e.g. micro- and mega-quartz) via a processes termed 'silicification' (Mueller et al., 1996; Mueller et al., 2009; Farber et al., 2015, Hofmann et al., 2014, Hanor and Duchac, 1990, and Gibson et al., 1983). During silicification (which can occur via hydrothermal alteration or later metasomatism), silica-rich fluids permeate porous material (tuffs/ individual volcanic flows) to produce silicified volcanic rocks of varying composition and $\mathrm{SiO}_{2}$ content (e.g., Brengman and Fedo, 2018). Under conditions of minor replacement, primary textures are preserved, and silicified rocks can be identified by petrographic characteristics (i.e. remnant volcanic textures like phenocrysts, glass shards, amygdules, fiamme, pumice fragments, etc.) and near-primary geochemistry. Well-preserved silicified volcanic rocks and associated chemical sedimentary rocks within the AGB are identifiable by standard geochemical proxies and petrographic indicators. To constrain mechanisms of quartz precipitation during silicification and chemical sedimentation within the depositional setting of the Abitibi Greenstone Belt, we pair standard whole-rock geochemical data with silicon and oxygen isotope data from individual quartz crystals using both in situ (Secondary Ion Mass Spectrometry - SIMS) and multi-crystal (Isotope Ratio Mass Spectrometry - IRMS) techniques. We demonstrate that silicified rocks differ in isotopic composition from chemical sedimentary rocks and could record distinct isotopic signatures that link to changing quartz precipitation rates, temperature, $\mathrm{pH}$, and/or the initial composition of the silicon reservoir in a dynamic subaqueous system influenced by hydrothermal activity (van den Boorn et al., 2007; 2010; Brengman et al., 2016; Brengman and Fedo, 2018). Well-preserved rocks from the AGB therefore provide a test scenario for interpreting geochemical and isotopic mobility during Archean hydrothermal alteration, and coupled $\delta^{18} \mathrm{O}$ and $\delta^{30} \mathrm{Si}$ signatures preserved in hydrothermal depositional settings have the potential to re-evaluate previous models for the thermal and chemical evolution of the hydrosphere.

\section{Geologic Context}

Within the AGB, Ayer et al. $(1998,2002,2005)$ and Ayer et al. (2002) define several volcanic and sedimentary litho-tectonic assemblages, which Thurston et al. (2008) divided into 7 volcanic episodes by age: pre-2750 Ma; the Pacaud (2750-2736 Ma); Deloro (2734-2724 Ma); Stroughton-Roquemaure (2723-2720 Ma); Kidd-Munro (2719-2711 Ma); Tisdale (2710-2704 Ma); and Blake River (2704-2695 Ma), and 2 sedimentary basins, the Porcupine-type (2690-2685 Ma) and Timiskaming-type (2676-2670 Ma). Broadly, the region experienced sub-greenschist to greenschist facies regional metamorphism (Fig. 1), with locally higher-grade zones developing at contacts to major batholiths (Easton, 2001). For the discussion of silicification and chemical sedimentation in the present work, we follow the stratigraphic nomenclature outlined by Thurston 
et al. (2008), and for readability, for the remainder of the paper we exclude the prefix "meta" to simplify rock names, although a minor degree of metamorphism is implied.

Volcanic rocks and associated chemical sedimentary rocks include the $>2750 \mathrm{Ma}$ Assemblage near Temagami, ON, the 2734-2722 Ma Deloro Assemblage near Timmins, ON, correlative Deloro Assemblage rocks that form the Hunter Mine Group near Duparquet, QC ( $2722 \mathrm{Ma}$ ), and younger (2704-2695 Ma) Blake River Assemblage rocks near Rouyn-Noranda (Figs. 1, 2). Previous research indicates autochthonous development of the volcano-sedimentary assemblages (Ayer et al., 2005); there is no evidence for tectonic transport of stratigraphy (Snyder et al., 2009, Thurston et al., 2012). Such preservation allows detailed age correlation of volcanosedimentary episodes (Thurston et al., 2008), and makes the Abitibi Greenstone Belt a locality well suited for the study of near primary Archean volcano-sedimentary assemblages, and their link to depositional system evolution. Chemical sedimentary rocks mark significant depositional gaps between many of the assemblages (Thurston et al., 2008). Relevant to the present study, the Deloro assemblage chemical sedimentary rocks exposed near Timmins, ON (Fig. 2A) correlate to silicified volcanic rocks of the Hunter Mine Group (also Deloro Assemblage), which outcrop near Duparquet, QC (Fig. 2; Brengman and Fedo, 2018). Based on the work of Thurston et al. (2008) (see text and references therein for detailed information regarding regional stratigraphic correlation), we can compare geochemical and isotopic signatures of comparative silica-rich rocks from Deloro Assemblage outcropping near Timmins, ON and Duparquet, QC to quantify systemscale silica deposition and mobility. In addition to chemical sedimentary rocks and silicified volcanic rocks of the Deloro Assemblage (2734-2722 Ma), we also compare data from the stratigraphically older Temagami iron formation (>2750 Ma), and the younger $(2698$ - $2696 \mathrm{Ma})$ Blake River Assemblage (Fig. 2C) to assess geochemical and isotopic evolution within the AGB depositional system. Overall, the sampling strategy includes rocks with a demonstrable chemical sedimentary origin from Temagami and the Deloro Assemblage, and silicified volcanic rock samples from the Deloro Assemblage, the Hunter Mine Group, and the Blake River Group (Fig. 2).

The Temagami iron formation (IF, Fig. 3A) forms part of the local Temagami greenstone belt (Ontario, Canada) and includes metasedimentary rocks (iron formation and shale), and metavolcanic units (Bowins and Heaman, 1991; Bau and Alexander, 2009). Overall, the region experienced lower greenschist facies metamorphism, allowing preservation of fine-scale banding and micro-crystallinity (Bennett, 1987; Fyon and Cole, 1989). The assemblage consists (in stratigraphic order) of meta-volcanic rocks overlain by iron formation and shales with turbidites. Iron formation samples collected for the present study come from a recently exposed road cut along Highway 11 (Table 1). Within this section, iron formation consists dominantly of interlayered oxide minerals (magnetite and hematite) and quartz (Fig. 3A).

Near Timmins, ON, the Deloro Assemblage consists of intact stratigraphic sequences of iron formation, mafic and felsic volcanic rock, and associated locally derived graphitic and sulfidic argillite, which flank syn-volcanic batholiths (Thurston et al., 2012). Thurston et al. (2008) provided regional stratigraphic evidence that such sedimentary deposition occurs during periods of volcanic quiescence. The Deloro Assemblage consists of three separate iron formation units (lower, middle, and upper), which interstratify with volcanic rocks (Fig. 2A, D, E). The middle and upper iron formations are well represented in outcrop and do not occur in close proximity to batholiths, so we focused sampling to these units (Fig. 2D, E). The middle iron formation consists of alternating sections of oxide, sulfide, and silicate facies (chert-rich) iron formation (Fig 3B, C) intercalated with heterolithic material interpreted as debris flows composed of mixed cherty and 
138 volcaniclastic material. Felsic volcanic rocks $(2728.1 \pm 1.6 \mathrm{Ma})$ underlie the IF, which is

139 conformably overlain by $2724.5 \pm 2.1 \mathrm{Ma}$ felsic volcanic rocks (Fig. 2D). The upper iron

140 formation (0.5-5 m thick) consists of chert and oxide-facies iron formation (Fig. 3D, E)

141 interstratified with felsic tuff (Houlé, 2006). Some layers show evidence for silica mobility (Fig.

$1423 \mathrm{D}$, silicification) and/or brecciation (Fig. 3E) potentially linked with increased hydrothermal

143 activity and volcanism at the top of the stratigraphic section. We collected samples of silicified,

144 fine-grained felsic volcanic rocks, sulfidic mudstone, sulfide-facies iron formation, oxide-facies

145 iron formation and heterolithic debris flow for the present study from the middle iron formation,

146 and iron formation samples, including some that show evidence of silicification, from the upper

147 iron formation (Table 1; Fig. 2E).

148 Correlative to the Deloro Assemblage near Timmins, ON, the Hunter Mine Group (HMG)

149 near Duparquet, QC represents a collapsed subaqueous caldera associated with volcanogenic

150 massive sulfide (VMS) deposition and associated hydrothermal alteration (Mueller and

151 Mortensen, 2002, Mueller et al., 2009). Near Lake Abitibi, the HMG outcrops on the southern

$152 \mathrm{limb}$ of an overturned, east-plunging anticline. The group displays features of sub-greenschist

153 facies metamorphism, and delicate volcanic textures remain identifiable and well-preserved

154 (Mueller et al., 2009; Brengman and Fedo, 2018). Felsic and mafic volcanic rocks interstratified

155 with volcaniclastic and iron-formation lithofacies characterize the HMG (Fig. 2B, F; Chown et al.,

156 2000; Mueller and Mortensen, 2002). Of interest to the present study are volcanic rocks silicified

157 during syn-formational hydrothermal alteration within the collapsed HMG caldera (Fig. 2F).

158 Petrographic and geochemical details for silicified samples AB-11-12 and AB-11-11 discussed

159 here were published in Brengman and Fedo (2018).

160 The Blake River Group (Corfu et al., 1989; Corfu, 1993; Mortensen, 1993; Galley and

161 van Breemen, 2002; Piercy et al., 2008) outcrops near Rouyn-Noranda, QC, and consists of a

162 10-km-thick sequence of mafic-felsic volcanic rocks (Fig. 2C, G; e.g., Dimroth et al., 1982;

163 Gibson and Watkinson, 1990; Péloquin et al., 1990). Regionally, the younger Porcupine and

164 Timiskaming assemblages (Ayer et al., 2002) overlie the Blake River Group, which crops out

165 south of the Destor-Porcupine fault and lies north of the Cadillac-Larder Lake break. Samples

166 for the present study include sample numbers Am. Basalt, and AB-13-08 thru AB-13-20 (Table

167 1), which represent variably silicified andesitic and basaltic rocks and an overlying silica-rich

168 exhalite unit (Fig. 2F, 3F) that caps an amygdaloidal pillow basalt (Fig. 2F, 3F).

\section{Analytical methods}

\subsection{Elemental Geochemistry}

Selected rock samples collected from outcrops were trimmed of modern weathering rinds, cut into $\sim 1 \mathrm{~cm}$ cubes, then powdered in a SPEX shatterbox instrument using an alumina ceramic dish and puck, with massive milky quartz inserted as blank runs between samples to clean the crushing surfaces. Powdered whole-rock samples were sent to Activation Laboratories Ltd. (Ancaster, Ontario) for geochemical analyses. They were prepared in a batch system (with a method reagent blank, certified reference material, and $17 \%$ replicates) and analyzed using a standard lithium metaborate/tetraborate fusion process for a suite of 46 elements. Major oxides and select trace elements $(\mathrm{Ba}, \mathrm{Sr})$ were measured using inductively coupled plasma optical emission spectrometry (ICP-OES) using either a combination simultaneous/sequential Thermo Jarrell-Ash ENVIRO II ICP or a Varian Vista 735 IC. Trace elements were analyzed by inductively coupled plasma mass spectrometry (ICP-MS) using either a Perkin Elmer Sciex ELAN 6000, 6100 
or 9000 ICP-MS. All unknowns were compared to USGS and CANMET certified reference materials (DNC-1, GBW 07113, LKSD-3, W-2a, SY-4, CTA-AC-1, BIR-1a, NCS DC86312, NCS DC70014, NCS DC70009, OREAS 100a, OREAS101a, JR-1; Table S1). Three blanks and five controls were analyzed per sample group with duplicates inserted every 15 samples, and instrument recalibration after every 40 samples. Six blind samples were also analyzed and compared to the original sample and a reproducibility (within 5\%) was determined based on multiple analyses of randomly selected samples across different analytical sessions. Detection limits are reported in Table S1.

\subsection{Isotope Geochemistry}

Samples were selected and screened based on major-, trace- and rare earth-element geochemistry and petrographic characteristics. Silicon and oxygen isotope measurements were made from a single, $1 \mathrm{mg}$ aliquot using a fluorination-IRMS method after Prentice et al. (2014). Oxygen and silicon tetrafluoride $\left(\mathrm{SiF}_{4}\right)$ were extracted from the same sample after reaction in heated Ni-tubes using bromine pentafluoride $\left(\mathrm{BrF}_{5}\right)$ fluorination. Triple oxygen isotope analyses $\left({ }^{16} \mathrm{O},{ }^{17} \mathrm{O},{ }^{18} \mathrm{O}\right)$ were conducted on $\mathrm{O}_{2}$ gas collected using $5 \AA$ molecular sieve, using a custom-built MAT 253 isotope ratio mass spectrometer at Western University. After the collection of $\mathrm{O}_{2}$, triple silicon isotope analyses $\left({ }^{28} \mathrm{Si},{ }^{29} \mathrm{Si},{ }^{30} \mathrm{Si}\right)$ were performed on $\mathrm{SiF}_{4}$ gas from the same sample. Replicate analyses of NBS-28 have a precision of $0.06 \%$ and $0.04 \%$ for $\delta^{29} \mathrm{Si}$ and $\delta^{30} \mathrm{Si}$ values, respectively. All Si-isotope values are reported using the NBS-28 standard using the format $\delta^{30} \mathrm{Si}=\left[\left({ }^{30} \mathrm{Si} /{ }^{28} \mathrm{Si}_{\text {sample }}\right) /\left({ }^{30} \mathrm{Si} /{ }^{28} \mathrm{Si}_{\text {standard }}\right)-1\right] \times 1000$. Oxygen isotope data are reported using the $\mathrm{V}$ SMOW standard using the format $\left(\delta^{18} \mathrm{O}=\left[\left({ }^{18} \mathrm{O} /{ }^{16} \mathrm{O}_{\text {sample }}\right) /\left({ }^{18} \mathrm{O} /{ }^{16} \mathrm{O}_{\text {standard }}\right)-1\right] \mathrm{x} 1000\right.$. All silicon and oxygen isotope data obtained via IRMS are reported in Supplementary Table S2.

Samples for SIMS (small rock chips and/or cut thin sections) were embedded in epoxy along with a silicon isotope quartz reference material (NBS-28, UNIL-Q1, or UTQ depending on the analytical session; Table S4), polished to $1 \mu \mathrm{m}$, mapped using Nikon petrographic microscope, and gold-coated $(30 \mathrm{~nm})$ prior to analysis. In situ Si-isotope $\left({ }^{30} \mathrm{Si} /{ }^{28} \mathrm{Si}\right)$ measurements were made using a CAMECA IMS 1280 SIMS instrument at the Swedish Museum of Natural History, Stockholm (NordSIMS facility). A ${ }^{133} \mathrm{Cs}+$ primary beam (ca. 5nA) with an incident energy of 20 $\mathrm{keV}$ was used to sputter secondary ions from specifically targeted $<20 \mu \mathrm{m}$ individual grains; microcrystalline domains were avoided (cf. ref. Marin-Carbonne et al., 2012) except during methodological testing. Sample charging was minimized by use of a low-energy normal-incidence electron gun. Secondary ions were measured at a mass resolution of $2,500(\mathrm{M} / \Delta \mathrm{M})$ by multicollection on Faraday detectors attached to low noise amplifiers housed in a thermally stabilized, evacuated chamber. The magnetic field was locked at high precision using an NMR field sensor. Fully automated analytical sessions included regularly bracketed unknowns between reference analyses and individual analyses and comprised a pre-sputter to remove the $\mathrm{Au}$ coat, beam centering, and 48 seconds ( $\mathrm{Si}$ ) of data acquisition. We report isotope values expressed in standard delta notation $\left(\delta^{30} \mathrm{Si}=\left[\left({ }^{30} \mathrm{Si} /{ }^{28} \mathrm{Si}_{\text {sample }}\right) /\left({ }^{30} \mathrm{Si} /{ }^{28} \mathrm{Si} i_{\text {standard }}\right)-1\right] \times 1000\right.$. Corrections for instrumental mass fractionation were made using UNIL-Q with a multi-crystal $\delta^{30} \mathrm{Si}$ value of $-0.13 \%$ determined at the University of Lausanne (Kleine et al., 2018), and UTQ with a multi-crystal $\delta^{30}$ Si value of 0.08 $\pm 0.01 \%$, determined at Western University, (different analytical sessions had separate internal standards). External reproducibility $(1 \sigma)$ for $\delta^{30} \mathrm{Si}$ of $\pm 0.15 \%$ was derived from the bracketing of analyses and propagated onto within-run uncertainties. All silicon isotope data obtained via 
SIMS are reported in Supplementary Tables S3 and S4. Table S3 contains a summary of NBS-28 corrected silicon isotope data, while analytical details and standards are included in Table S4.

\section{Petrography 4.1 Chemical sedimentary rocks}

We examined 10 chemical sedimentary rocks in thin section, 3 of which demonstrated evidence of silicification in the field (Fig. 3D, E; Table 1). Overall, all samples (independent of grain size and assemblage) possess a dominant quartz, Fe-oxide $\pm \mathrm{Fe}-\mathrm{Mg}$ silicate mineralogy, and fine-scale banding. Samples TEMcf and TEMj from the Temagami greenstone belt consist of predominantly microcrystalline quartz, interlayered with hematite and magnetite (Fig. 4A). Texturally, samples are finely laminated at the $\mathrm{mm}$-scale, with rare mega-quartz veins. From the $\sim 2734-2722$ Ma Deloro Assemblage, all samples show banding at both the millimeter and meter scale, with layers alternating between iron-rich and silica-rich phases. Hematite is notably absent from the Deloro assemblage; magnetite and pyrite form the dominant iron-rich phases. Quartz is the dominant silicate phase, although some acicular minnesotaite is present in select bands. Crystal sizes of quartz vary from micro-quartz (e.g., Fig. 4B, C; Table 1) to mega-quartz (Fig. 4D; Table 1). Spherules are present within some Middle Deloro iron formation samples (Fig. $4 \mathrm{C}$ ) and consist of fewer than ten clustered mega-quartz crystals that display radial extinction.

\subsection{Silicified volcanic rocks}

We examined 17 silicified volcanic rock samples, and 4 samples with a mixed volcanic and chemical sedimentary origin (e.g. heterolithic debris flow material and fragmented iron formation hosted within a matrix of volcanic material; Fig. 3E). We focus the description here on the attributes of quartz as it directly links to the silicification process. Additional petrographic observations for these silicified volcanic rocks can be found in Baldwin (2011, Deloro Assemblage), Brengman and Fedo (2018, HMG), and Gibson (1983, Blake River Group). Overall, samples from the HMG display patchy silicification (regionally associated with sulfide mineralization; Fig. 5A), and variable preservation of volcanic features including phenocrysts, remnant glass shards, lapilli, and volcanic fragments (Brengman and Fedo, 2018). Of interest to the present study, select samples preserve quartz and feldspar phenocrysts both inside and external to patches of silicified material. Silicified patches consist of micro-quartz (Fig. 5A) that replaces fine-grained matrix material (Brengman and Fedo, 2018). With clearly identifiable quartz phenocrysts and areas of silicification, we targeted isotopic measurement of quartz formed due to igneous processes to compare to quartz formed during silicification (Table 1). We expand on the different isotopic signatures of quartz in section 6. From the Blake River Assemblage, we examined andesitic and basaltic rocks that show patchy silicification at the field and thin section scale (Fig. 5B, C respectively), and an exhalite (Fig. 5D). Mega-quartz is present in the silicified volcanic rocks as either patches (Fig. 5B), or quartz-filled amygdules (Fig. 5C). Micro-quartz and a minor amount of fine-grained sericite dominate the exhalite unit (Fig.D).

Samples with a demonstrable chemical sedimentary origin were selected for geochemistry and isotope analyses based on previously established criteria for preservation (Marin-Carbonne et al., 2012). Silicified volcanic rock samples are less well represented in the literature, so we sampled a large range of crystal sizes and host rock lithologies for comparative purposes. Overall, for silicified volcanic rocks, we targeted micro-quartz and mega-quartz within silicification patches 
and filling amygdules, as well as micro-quartz within the exhalite for in situ isotopic analysis 275 (Table 1).

\section{Geochemistry 5.1 Major and trace element data}

Samples divide into three geochemically distinct groups: chemical sedimentary rocks; silicified volcanic rocks; and rocks with a volcaniclastic origin and/or a mixed chemical sedimentary origin (Table 1; Fig. 6A, B). As expected, rocks with a clear chemical sedimentary origin show lower major-element abundances for elements associated with detrital/igneous origin (e.g., $\mathrm{Al}_{2} \mathrm{O}_{3}$ ) and higher overall iron contents compared to volcanic and volcaniclastic rocks (Table $\mathrm{S}$; Fig. 6A; e.g., $\mathrm{Al}_{2} \mathrm{O}_{3}$ in feldspathic volcanic rocks). With respect to trace element signatures, shale-normalized europium-anomaly values range from $2.9-4.75$ and $\mathrm{Y} / \mathrm{Ho}$ values range from $28.33-36.11$ for chemical sedimentary rocks (Fig. 6B). Such values are consistent with other measurements in the region (e.g. - Temagami IF EusN/EusN*3.0-4.3, Y/Ho $=36-59$; Bau and Alexander, 2009) and likely indicate the presence of hydrothermal fluids. Rocks with a mixed chemical sedimentary and/or volcaniclastic origin possess $\mathrm{Eu}_{\mathrm{SN}} / \mathrm{Eu}_{\mathrm{SN}} *$ values ranging from 1.52 3.16 , and $\mathrm{Y} / \mathrm{Ho}$ values of $25.2-26.27$. Overall, samples of mixed origin possess a distinct slope, with $\mathrm{Pr}_{\mathrm{SN}} / \mathrm{Yb}_{\mathrm{SN}}$ values ranging from $1.24-2.43$, compared to chemical sedimentary samples $\left(\operatorname{Pr}_{S N} / \mathrm{Yb}_{S N}=0.17-0.76\right)$ and extrusive volcanic samples $\left(\operatorname{Pr}_{S N} / \mathrm{Yb}_{\mathrm{SN}}\right.$ (basalt) $=0.33-0.75$; $\mathrm{PrSN}_{\mathrm{SN}} / \mathrm{Yb}_{\mathrm{SN}}$ (andesite) $=0.41-0.67 ; \mathrm{PrSN}_{\mathrm{SN}} / \mathrm{Yb}_{\mathrm{SN}}$ (exhalite) $=0.95$ ). Silicified volcanic rocks have dominantly positive eurpoium anomalies $\left(\mathrm{Eu}_{\mathrm{SN}} / \mathrm{EuSN}^{*}=0.80-1.42\right.$ (basalt), $0.92-1.78$ (andesite), 0.71 (exhalite)), and $\mathrm{Y} / \mathrm{Ho}$ values within the range expected for igneous rocks and their clastic derivatives (Bau 1993; Y/Ho = 27.27 - 28.21 (basalt), $27.67-29.47$ (andesite), and 29.68 (exhalite)). Overall, measured major- and trace-element values are consistent with regional volcanic rocks, though the presence of a shale-normalized positive europium anomaly indicates varying degrees of hydrothermal alteration, which is expected in the VMS-producing region.

\subsection{Silicon and oxygen isotope geochemistry (IRMS)}

We measured silicon $\left(\delta^{30} \mathrm{Si}\right)$ and oxygen $\left(\delta^{18} \mathrm{O}\right)$ isotope compositions of separated quartz crystals from two iron formation samples (AB-13-65, TEM-cf), five silicified volcanic rocks (AB11-11 thru AB-11-34), and one sample of silicified iron formation (AB-13-72) via IRMS using methods developed in the Laboratory for Stable Isotope Science at Western University (section 3). In addition, we measured the whole-rock (multi-phase) isotope composition for AB-11-11 for comparison to the quartz separate. All data (samples and duplicates) are reported in Table S2, and Figure 7.

Iron formation samples possess ${ }^{30} \mathrm{Si}$-depleted silicon isotope values $\left(\delta^{30} \mathrm{Si}_{\mathrm{NBS}-28}=-1.127\right.$ to $-0.745 \pm 0.03 \%(2 \sigma))$, and ${ }^{18} \mathrm{O}$-depleted oxygen isotope values $\left(\delta^{18} \mathrm{O}_{\mathrm{V}-\mathrm{SmOW}}=11.36\right.$ to $12.78 \pm$ $0.03 \%(2 \sigma))$ compared to expected values for chemical sedimentary rocks. Quartz formed in equilibrium with seawater at temperatures ranging from $10-30{ }^{\circ} \mathrm{C}$, should range from $\Delta{ }^{18} \mathrm{O}_{\text {qtz-fluid }}$ $=36.3-31.7 \%$, if $\delta^{18} \mathrm{O}_{\text {SEAWATER }}=-1 \%$ (Pollington et al., 2016). Overall, non-silicified samples possess ${ }^{30} \mathrm{Si}$-depleted silicon isotope values (Fig. 7) comparable to various other Archean iron formations measured using the same technique (Brengman, 2015). Silicified volcanic rocks possess silicon isotope values ranging from $\delta^{30} \mathrm{Si}_{\mathrm{NBS}-28}=-0.289$ to $0.257 \pm 0.03 \% 0(2 \sigma)$, which is comparable to values measured for modern altered igneous rocks $\left(\delta^{30} \mathrm{Si}\right.$ IOPD site $1256=-0.27$ to -0.38 
$\%$; Yu et al., 2018; and $\delta^{30} \mathrm{Si}_{\mathrm{MORB}}=-0.27 \pm 0.06 \%$; Savage et al., 2014) and multi-crystal bulk silicate earth estimates $(-0.28 \pm 0.06 \%$ ( $2 \sigma)$; Fitoussi et al., 2009; $-0.29 \pm 0.06 \%$; Savage et al., 2014). The measured $\delta^{30} \mathrm{Si}$ values from the AGB are also comparable to Archean silicified basalt (Fig. 7; Abraham et al., 2011). Oxygen isotope values of quartz within silicified volcanic rocks $\left(\delta^{18} \mathrm{O}_{\text {V-SMOW }}=10.53\right.$ to $\left.14.67 \pm 0.03 \%(2 \sigma)\right)$ are ${ }^{18} \mathrm{O}$-enriched compared to average regional volcanic rocks (whole rock values range from 6-12 \%, Beaty, 1980). The whole-rock (mixed phase) sample (AB-11-11 WR) possesses silicon and oxygen isotopes values expected for igneous rocks, $\delta^{30} \mathrm{Si}_{\mathrm{NBS}-28}=-0.029 \pm 0.03 \%(2 \sigma)$ and $\delta^{18} \mathrm{O}_{\mathrm{V}-\mathrm{SMOW}}=10.02 \pm 0.03 \%$ o $(2 \sigma)$, respectively. Overall, silicified volcanic samples and the silicified iron formation sample have ${ }^{30} \mathrm{Si}$-enriched values compared to chemical sedimentary rocks (Fig. 7). We discuss the potential reasons for silicon isotope differences of quartz from chemical sedimentary rocks and silicified volcanic rocks and explore internal silicon isotope variation between different quartz textures in section 6 .

As a point of reference, we compare AGB data to the well-studied volcanic units (Theespruit, Hooggenoeg and Kromberg Formations) in the Paleoarchean Barberton Greenstone Belt, South Africa (light gray, triangle data points Fig. 7; Abraham et al., 2011) and to various Archean iron formation units (light gray square data points, Fig. 7). As illustrated in Figure 7 (Table S2), silicified basaltic rocks from the Barberton samples display ${ }^{30} \mathrm{Si}$-enriched $(\sim-0.5$ to $+0.5 \%)$ and ${ }^{18} \mathrm{O}$-enriched values $(\sim+10$ to $+15 \%)$ relative to non-silicified counterparts, showing a strong positive correlation between $\mathrm{Si}$ and $\mathrm{O}$. Furthermore, all of the volcanic rocks are enriched in ${ }^{30} \mathrm{Si}$ relative to the compiled data from iron formations (Fig. 7). Similar to the Barberton array, silicified volcanic rocks from the AGB show the same enrichment in ${ }^{30} \mathrm{Si}$ relative to compiled iron formation, including measurements of $\mathrm{Si}$ and $\mathrm{O}$ isotope compositions from 2 samples of AGB iron formation (Fig. 7; multi-crystal IRMS analyses). Oxygen isotope values of samples from the AGB overlap with other Archean samples with a similar genesis (Fig. 7), and are consistent with temperature-dependent isotope fractionation occurring during precipitation of quartz influenced by hydrothermalism (Abraham et al., 2011), rather than seawater (values are ${ }^{18} \mathrm{O}$-depleted compared to expected values for seawater precipitates). Some of the slight ${ }^{18} \mathrm{O}$-enrichment observed in quartz separates from silicified volcanic rocks (compared to regional volcanic rocks Beaty, 1980) could be due to the potential presence and/or preferential replacement of hydrated volcanic glasses (Taylor et al., 1966). Of note, there is a significant difference (3.5\%o offset) between oxygen isotope compositions of AB-11-11 WR (mixed phases) and AB-11-11 (quartz only). Such disparity could indicate that quartz is not in equilibrium with the rest of the rock, possibly due to heterogeneous oxygen isotope exchange during hydrothermal activity and fluid flow, similar to samples in King et al. (1997). In total, the overlapping silicon isotope values for like rock types between localities suggest similar quartz precipitation and dissolution mechanisms between the Abitibi and Barberton samples, which broadly formed in similar depositional systems. We explore the development of the silicon isotope signature further in section 5.3 below where we incorporate SIMS data.

\subsection{Silicon isotope geochemistry (SIMS)}

In addition to measuring silicon and oxygen isotope values of quartz separates and one whole-rock (multi-phase) sample using IRMS (Fig. 7; Table S2), we measured single-crystal silicon isotope compositions of quartz within 7 silicified volcanic rocks $(\mathrm{n}=120), 3$ IF samples ( $\mathrm{n}$ $=121)$, and 2 silicified IF samples $(\mathrm{n}=50)$ using secondary ion mass spectrometry (SIMS). All SIMS data are reported in Table S3, S4, and Figures 8-10. To quantify intra- and inter-sample 
heterogeneity, we measured micro- and mega-quartz of distinct textures in each sample (Table 1 summarizes SIMS targets). We utilized petrographic features combined with major- and traceelement geochemistry to evaluate sample preservation. We also compared micro- and mega-quartz $\delta^{30} \mathrm{Si}$ values of silicified rocks between assemblages to verify comparative preservation.

From Temagami, we measured micro- and mega-quartz (Table 1) from samples of iron formation along single layers, and across layers but observed no systematic variation (Table S3, S4). From the Deloro assemblage near Timmins, we measured individual $\delta^{30} \mathrm{Si}$ values of microand mega-quartz and quartz spherules from samples of non-silicified and silicified IF (Tables 1, $\mathrm{S} 3$, and $\mathrm{S} 4 ; \mathrm{n}=76$ ). Silicon isotope compositions of quartz within the IF samples (Temj, Temcf, AB-13-70) range from $\delta^{30} \mathrm{Si}_{\mathrm{NBS}-28}=-3.21 \pm 0.21 \%$ to $0.52 \pm 0.40 \%$ (Fig. 8, 9A, B; Tables 1, S3, and S4; $\mathrm{n}=45$ ). Silicified IF samples from the Upper Deloro (AB-13-72, AB-13-74; Tables 1, S3, and $\mathrm{S} 4 ; \mathrm{n}=50)$ possess silicon isotope values ranging from $\delta^{30} \mathrm{Si}_{\mathrm{NBS}-28}=-3.88 \pm 0.15 \%$ to $0.15 \pm$ $0.21 \%$ (Fig. 8, 9C). Despite a crystal size difference (Table 1) there is no systematic isotopic variation between sample AB-13-72 and AB-13-74 (Tables S3, S4). Overall, IF samples (silicified and un-silicified) display ${ }^{30} \mathrm{Si}$-depleted values compared to bulk silicate earth estimates (Savage et al., 2014; Fitoussi et al., 2009) and correlative silicified volcanic rocks.

For comparison to chemical sedimentary rocks described above, we measured examples of chert fragments (of a silicified or chemical sedimentary origin) within volcanic rocks. Chert fragments exist within silicified horizons of the Deloro Assemblage at the Timmins and the Duparquet localities (Fig. 3E; Baldwin et al., 2011 and Thurston et al., 2008). Near Timmins, sample AB-13-76 (Figs. 8, 9D) contains chert fragments in a volcanic matrix (Fig. 3E). Geochemical data (Fig. 5A, B) confirms the sample is of mixed chemical and volcanic origin (Table S1). Micro-quartz crystals within the chert fragments possess silicon isotope values ranging from $\delta^{30} \mathrm{Si}_{\mathrm{NBS}-28}=-0.77 \pm 0.15 \%$ to $1.04 \pm 0.14 \%$ (Fig. $8 \mathrm{D}$; Tables S3, S4; $\mathrm{n}=15$ ). Compared to the underlying iron formation units (Fig. 8, 9A-C), the silicified chert fragments possess ${ }^{30} \mathrm{Si}-$ enriched values. From the Deloro Assemblage near Duparquet, sample AB-11-12 from the HMG shares a similar mixed volcanic/silicified origin to AB-13-76 (Mueller and Mortensen, 2002; Chown et al., 2000; geochemical data reported in Brengman and Fedo, 2018). Micro-quartz in chert fragments ranged from $\delta^{30} \mathrm{Si}_{\mathrm{NBS}-28}=-0.72 \pm 0.37 \%$ to $0.82 \pm 0.37 \%$ (Figs. $8,9 \mathrm{E}$; Tables $\mathrm{S} 3, \mathrm{~S} 4 ; \mathrm{n}=14)$. Overall, silicon isotope values from chert fragments hosted within silicified volcanic rocks of the Deloro Assemblage from both the Timmins and Duparquet localities overlap and share similar ranges, and are ${ }^{30} \mathrm{Si}$-enriched compared to local chemical sedimentary rocks (chert layers within iron formation).

To determine the relationship between silicon isotope values of silicified rocks and chemical sedimentary rocks, we measured micro- and mega-quartz within variably silicified andesite, as well as thin exhalative unit that drapes an amydaloidal basalt associated with VMSmineralization from the Blake River Group near Rouyn-Noranda (Figs. 8, 9E-G). Overall, silicified andesite samples range from $\delta^{30} \mathrm{Si}_{\mathrm{NBS}-28}=-0.82 \pm 0.15$ to $0.83 \pm 0.19 \%$, with one outlier point that extends to $\delta^{30} \mathrm{Si}_{\mathrm{NBS}-28}=-1.90 \pm 0.15 \%$ (Fig. 8, 9F; Tables S3, S4; $\mathrm{n}=64$ ). Silicon isotope compositions of individual micro-quartz measured within exhalitive sample AB-13-09 ranges from $\delta^{30} \mathrm{Si}_{\mathrm{NBS}-28}=-0.04 \pm 0.22$ to $1.00 \pm 0.20 \%$ (Figs. 8, 9G; Tables S3, S4; $\mathrm{n}=3$ ), while quartz within amygdules in the underlying basalt sample (AMYG) ranges from $\delta^{30} \mathrm{Si}_{\mathrm{NBS}-28}=-1.22$ \pm 0.15 to $1.14 \pm 0.16 \%$ (Fig. 8, 9G; Tables S3, S4; $\mathrm{n}=24$ ). Similar to chert fragments within silicified horizons of the Deloro Assemblage, all silicified volcanic rock samples are ${ }^{30}$ Si-einriched compared to regional chemical sediments. 
To specifically assess internal heterogeneity between igneous-derived quartz phenocrysts and micro-quartz associated with the silicification process within the same sample, we measured the silicon isotope values of quartz phenocrysts within silicification patches, and external to silicification patches, as well as micro-quartz associated with silicification within the same sample - sample AB-11-11 from the Deloro Assemblage (HMG) near Duparquet (Fig. 10). Silicon isotope values $\left(\delta^{30} \mathrm{Si}\right)$ of quartz phenocrysts inside silicified areas range from $\delta^{30} \mathrm{Si}_{\mathrm{NBS}-28}=-0.81 \pm 0.18 \%$ to $0.27 \pm 0.17 \%$ ( $(n=38$; Fig. $10 \mathrm{~B})$, and were comparable to values for quartz phenocrysts outside of silicified areas $\left(n=19 ; \delta^{30} \mathrm{Si}_{\mathrm{NBS}-28}=-0.58 \pm 0.23 \%\right.$ to $0.76 \pm 0.20 \%$; Fig. 10B). Silicon isotope compositions of micro-quartz crystals from silicified volcanic matrix material $\left(\mathrm{n}=6 ; \delta^{30} \mathrm{Si}_{\mathrm{NBS}-28}=\right.$ $-1.06 \pm 0.22 \%$ to $0.16 \pm 0.20 \%$; Fig. $10 \mathrm{~B}$ ) span a similar range of values of both phenocryst populations when considering error. All measured silicon isotope data for sample AB-11-11 compares to regional silicified volcanic rocks, as well as magmatic quartz and high-temperature hydrothermal quartz values measured within modern volcanic samples from Iceland (Kleine et al., 2018). Intra- and inter-sample heterogeneity could link to genetic mechanisms for quartz precipitation or minor differences in the local geochemical environment. We explore possible explanations for the observed systematic heterogeneity between rock types in the following section.

\section{Silicon isotope fractionation and silica mobility in the $\sim 2.7$ Ga AGB depositional system}

To determine potential explanations for the observed silicon isotope heterogeneity in the SIMS data from the AGB (Figs. 8-10), we consider silicon isotope studies of modern hydrothermal systems and recent experimental work on quartz precipitation. Silicon isotope fractionation occurs under varying geochemical and system conditions (open-to-closed, $\mathrm{pH}$, temperature gradients; $\left(\Delta^{30} \mathrm{Si}_{\text {precipitate-solution }}>2.5\right.$ - $5 \%$; Oelze et al., 2014; 2015; Opfergelt et al., 2010; Delstanche et al., 2009; Geilert et al., 2014a; 2015). In modern hydrothermal systems such as in Iceland (Kleine et al., 2018), heterogeneous silicon isotope values measured in high- and low-temperature quartz are the result of kinetic mineral-fluid fractionation. In the Iceland system (Kleine et al., 2018), ${ }^{30} \mathrm{Si}$ depleted values likely result from near-surface cooling and open-system precipitation within the hydrothermal fluid conduit. As the fluid cooled, the chemical and isotopic composition of both the fluid, and subsequently the precipitated minerals (silicates) would evolve. For comparison to the AGB data presented in this paper, Figure 8 shows the ranges of measured silicon isotope values for low-temperature $\left(<150^{\circ} \mathrm{C}\right)$ quartz and other silica polymorphs, high-temperature quartz (200$400{ }^{\circ} \mathrm{C}$ ) and magmatic quartz $\left(>550{ }^{\circ} \mathrm{C}\right)$ reported in Kleine et al. (2018). Within modern hydrothermal systems, eruptive volcanic rocks and tuffaceous units interstratify with minerals precipitated from hydrothermal fluids mixed with seawater, and silicified rocks at/below the seafloor. In the AGB system, the Blake River Assemblage, Amulet andesite and basalt, and Hunter Mine Group samples represent variably silicified eruptive volcanic rocks - tuffaceous units; chert and IF of the Deloro Assemblage represent precipitated chemical sedimentary rocks. Separating AGB data by quartz genesis pathway (chemical sedimentary v. silicified volcanic) shows that silicon isotope values display the same range as in modern hydrothermal systems for low- and high-temperature quartz (Fig. 8). Such overlap between ancient and modern samples is consistent with the hypothesis that quartz precipitated within VMS-producing systems in Algoma-type IF and associated silicified rocks forms via similar mechanisms as quartz precipitation in modern hydrothermal systems. Consequently, we interpret the silicon isotope heterogeneity within the 
AGB sample set to result from evolving water-rock ratios and fluid composition in a hydrothermal 457 system.

Figure 11 follows the evolution of a fluid through a hydrothermal system (after Hopkinson, 1999). Seawater would likely have a silicon isotope composition controlled by the balance between hydrothermal and continental inputs to the ocean $\left(\delta^{30} \mathrm{Si}= \pm 0 \%\right.$; van den Boorn et al., 2007; Kleine et al., 2018). Within modern hydrothermal systems, seawater $\left(\mathrm{T}=\sim 2^{\circ} \mathrm{C}, \mathrm{pH}=8.1\right.$, circle 1) permeates pores and fractures within igneous rocks (Franklin et al., 2005; Fig. 11, circle 2). Beneath the seafloor, in the volcanic pile, magmatic fluids $\left(\mathrm{T}=\sim 363^{\circ} \mathrm{C}, \mathrm{pH}=3.0\right)$ mix with cooler seawater (Franklin et al., 2005; Von Damm et al., 1991; Fig. 11, circle 2), and some elements are leached out of the host rocks, while others precipitate as concentrations in solution reach saturation (Franklin et al., 2005; Von Damm et al., 1991). Beneath the water-rock interface, quartz precipitates in fractures and pore spaces, which then progressively limits fluid circulation, a process that leads to extensive silicification of the host rock (Hopkinson et al., 1999; Fig. 11, circle 3). Such precipitation often occurs under lower water-to-rock ratios, and as a result, silicon isotope signatures should closely reflect the host rock $\left(\delta^{30} \mathrm{Si}_{\text {volc }}=\sim 0 \% ; \delta^{30} \mathrm{Si}_{\text {chemsed }}=\sim \leq 0 \%\right.$; Fig. $\left.9 \mathrm{H}\right)$. Silicified volcanic rocks (Fig. 11, circle 3) in greenstone belts could represent the altered portion of hydrothermal systems, where temperature would be high compared to seawater, and precipitation rates could vary widely. Upward convecting fluid escapes from the system in focused streams at the hydrothermal vents. In modern basalt-hosted systems, these focused acidic fluids $(\mathrm{pH}=\sim 3.0)$ have a wide range of temperatures $\left(\mathrm{T}=23^{\circ} \mathrm{C}-367^{\circ} \mathrm{C}\right.$; Reeves et al., 2014; Fig. 11, circle 4). At this point, the system returns to open conditions within respect to quartz precipitation, where the water-to-rock ratio is likely high (Franklin et al., 2005). Conductive cooling at this hydrothermal-seawater interface results in precipitation of quartz, and deposition of the quartzrich portion of chemical sedimentary rocks on the seafloor (Franklin et al., 2005; Fig. 11, circle 5). The high temperature of fluids yields quartz saturation at temperatures much greater than $100{ }^{\circ} \mathrm{C}$ (Rimstidt and Barnes, 1980), and upon contact with substantially cooler ambient seawater (near 1 ${ }^{\circ} \mathrm{C}$ ) across a distance as little as $5 \mathrm{~cm}$ from the hydrothermal fluid, $\mathrm{SiO}_{2}$ phases (amorphous $\mathrm{SiO}_{2}$, opal-A, quartz; Hopkinson et al., 1999) actively precipitate (Von Damm et al., 1991). As hydrothermal systems evolve, both temperature and precipitation rate change (Hopkinson et al., 1999), and different metals precipitate as a function of temperature. Oxidized iron phases precipitate predominantly in lower temperature hydrothermal systems (though still at temperatures higher than ambient seawater; Otake et al., 2007).

The role of hydrothermal fluids in the formation of Archean iron formations has been previously suggested (Isley, 1995; Isley and Abbott, 1999), with a specific focus on iron delivery mechanisms. We support that quartz-saturated, high-temperature fluids could precipitate silica phases upon contact with cold seawater to form Si-rich layers in iron formations within hydrothermally influenced depositional systems - a process very similar to what occurs modern vent systems. Chemical sedimentary rocks would show complex interlayering with volcanic tuffaceous units that deposit during active volcanism, which is how the stratigraphy of the Abitibi Greenstone Belt is assembled (Fig. 2). Other Archean IF localities share this stratigraphic architecture (IF associated with volcanic rocks and their silicified equivalents; Kimberley, 1979; Konhauser et al., 2017), which is significantly different from younger, Proterozoic assemblages (Superior-type IF). Proterozoic iron formations commonly possess a granular texture - containing sand-sized, transported grains and sedimentary structures indicative of wave action, in addition to being grouped stratigraphically with thick packages of sandstones, and mudstones. Because of the well-documented range in depositional settings, iron formations are expected to acquire and 
preserve basin-specific geochemical attributes. Specifically, we caution that isotope records that group quartz (and potentially other minerals) from all iron formations through time will include regional isotopic signatures, influenced by local hydrothermalism, rather than capturing a picture of ocean evolution through time.

\section{Conclusions}

We measured whole rock major and trace element geochemistry and silicon and oxygen isotopes using both in situ and multi-crystal techniques of various iron formations, and silicified volcanic rocks from the $\sim 2.7 \mathrm{Ga}$ Abitibi Greenstone Belt, Canada. Within the Abitibi depositional system, we conclude:

(1) silicon and oxygen isotope values of silicified volcanic rocks are different from associated chemical sedimentary rocks;

(2) micro-scale heterogeneity observed within silicon isotope values of chemical sedimentary rocks is likely primary, and links to near-surface cooling and open system precipitation within the hydrothermal fluid conduit, similar to quartz precipitating in modern hydrothermal systems in Iceland;

(3) silicified volcanic rocks often possess near igneous silicon isotope values, close to those of modern oceanic crust.

Together, these results suggest that primary silicon isotope signatures preserved in Archean rocks, and can be used to distinguish between quartz precipitating via silicification versus chemical sedimentation.

Interpreting the origin, diversification, and radiation of early life critically links to detangling the thermal and geochemical evolution of the Precambrian ocean. Rocks with the potential to record primary signatures of ocean chemistry and temperature include marine chemical sedimentary rocks such as chert and iron formation. However, metamorphism, metasomatism, and hydrothermal overprinting may obscure primary geochemical and textural attributes of such rocks within many Archean greenstone belt terranes, making it difficult to discern genesis. Consequently, there is a need to identify a robust geochemical proxy that reliably distinguishes between chemical sedimentary rocks and their altered look-alikes. Silicon isotope heterogeneity appears to be preserved through metamorphism (Brengman et al., 2016), and so perhaps could be used as a tool to distinguish chemical sedimentary rocks from their silicified equivalents in metamorphosed terranes. 


\section{Data Availability}

All data for the present study are available in Supplementary Tables S1 - S4 to be published with the peer-reviewed manuscript and available by request.

\section{Acknowledgments}

This work was funded by NASA grant EXOB08-0063 awarded to C.M. Fedo, and student research grants awarded to L.A. Brengman from ExxonMobil, the Geological Society of America, the Sedimentary Division of GSA, and the Department of Earth and Planetary Sciences at the University of Tennessee. The University of Minnesota - Duluth provided additional funding for travel to analytical facilities and additional fieldwork for L.A. Brengman. The NordSIMS facility is a joint Swedish-Icelandic infrastructure operated under Swedish Research Council grant 201406375 .

\section{Author contributions}

L.A. Brengman and C.M. Fedo planned the research. L.A. Brengman, C.M. Fedo, and M.J. Whitehouse collected samples, and performed silicon isotope analyses. I. Jabeen and L.A. Brengman completed IRMS analyses in the lab directed by N.R. Banerjee at Western University. L.A. Brengman and C.M. Fedo interpreted the data with input by M.J. Whitehouse, N. Banerjee, and I. Jabeen. L.A. Brengman and C.M. Fedo wrote the paper with input from M.J. Whitehouse, N.R. Banerjee, and I. Jabeen. 


\section{List of References}

1. Abraham, K., Hofmann, A., Foley, S.F., Cardinal, D., Harris, C., Barth, M.G., André, L. Coupled silicon-oxygen isotope fractionation traces Archean silicification. Earth and Planetary Science Letters 301, 222-230 (2011).

2. André, L., Cardinal, D., Alleman, L.Y., Moorbath, S. Silicon isotopes in 3.8 Ga West Greenland rocks as clues to the Eoarchaean supracrustal Si cycle. Earth and Planetary Science Letters 245, 162-173 (2006).

3. Baldwin, G. J., Thurston, P. C., Kamber, B.S. High-precision rare earth element, nickel, and chromium chemistry of chert microbands pre-screened with in-situ analysis. Chemical Geology 285: 133-143 (2011).

4. Ayer, J.A., Trowell, N.F., Amelin, Y., and Corfu, F. Geological compilation of the Abitibi greenstone belt: Toward a revised stratigraphy based on compilation and new geochronology results. Ontario Geological Survey Miscellaneous Paper 169: 4-1-4-14 (1998).

5. Ayer, J., Amelin, Y., Corfu, F., Kamo, S., Ketchum, J.F., Kwok, K., and Trowell, N.F., Evolution of the Abitibi greenstone belt based on U-Pb geochronology: Autochthonous volcanic construction followed by plutonism, regional deformation and sedimentation: Precambrian Research, 115; 63-95 (2002).

6. Ayer, J.A., Thurston, P. C., Bateman, R., Dubé, B., Gibson, H. L., Hamilton, M. A., Hathway, B., Hocker, S.M., Houlé, M., Hudak, G.J., Ispolatov, V., Lafrance, B., Lesher, C.M., MacDonald, P.J., Péloquin, A.S., Piercey, S.J., Reed, L.E., and Thompson, P.H. Overview of results from the Greenstone Architecture Project: Discover Abitibi Initiative: Ontario Geological Survey Open File Report 6154: 1-125 (2005).

7. Bau, M., Alexander, B.W., Distribution of high field strength elements (Y, Zr, REE, Hf, Ta, $\mathrm{Th}, \mathrm{U})$ in adjacent magnetite and chert bands and in reference standards FeR-3 and FeR-4 from the Temagami iron-formation, Canada, and the redox level of the Neoarchean ocean. Precambrian Research 174: 337-346 (2009).

8. Beaty, D.W., Taylor, H.P. Some Petrologic and Oxygen Isotopic Relationships in the Amulet Mine, Noranda, Quebec, and Their Bearing on the Origin of Archean Massive Sulfide Deposits. Economic Geology 77: 95-108 (1982).

9. Bennett, G., Geology of the Northeast Temagami area, District of Nipissing. Ontario Geological Survey Report 163 (1978).

10. Boggs, S. Principles of Sedimentology and Stratigraphy, $3^{\text {rd }}$ edition, Prentice Hall, 726 p. (2001).

11. Brengman, Latisha Ashley, "Distinguishing primary versus secondary geochemical and silicon isotope characteristics of Precambrian chert and iron formation" $\mathrm{PhD}$ diss., University of Tennessee, (2015). 
12. Brengman, L.A., Fedo, C. M., and Whitehouse, M. J. Micro-scale silicon isotope heterogeneity observed in hydrothermal quartz precipitates from the $>3.7 \mathrm{Ga}$ Isua Greenstone Belt, SW Greenland. Terra Nova 28.1, 70-75 (2016).

13. Brengman, L. A., Fedo, C. M. Development of a mixed seawater-hydrothermal fluid geochemical signature during alteration of volcanic rocks in the Archean $(\sim 2.7 \mathrm{Ga})$ Abitibi Greenstone Belt, Canada. Geochimica et Cosmochimica Acta 227, 227-245 (2018).

14. Chakrabarti, R., Knoll, A. H., Jacobsen, S. B., Fischer, W. W. Si isotope variability in Proterozoic cherts. Geochimica et Cosmochimica Acta 91, 187-201 (2012).

15. Chown, E. H., N'dah, E., Mueller, W. U. The relation between iron-formation and low temperature hydrothermal alteration in an Archean volcanic environment. Precambrian Research 101: 263-275 (2000).

16. Corfu, F., The evolution of the southern Abitibi greenstone belt in light of precise U-Pb geochronology. Economic geology, 88: 1323-1340 (1993).

17. Corfu, F., Krogh, T.E., Kwok, Y.Y., and Jensen, L.S., U-Pb geochronology in the southwestern Abitibi greenstone belt, Superior province. Canadian Journal of Earth Sciences, 26: 747-1763 (1989).

18. Delstanche, S., Opfergelt, S., Cardinal D., Elsass, F., André L., Delvaux, B. Silicon isotopic fractionation during adsorption of aqueous monosilicic acid onto iron oxide. Geochimica et Cosmochimica Acta 73, 923-934 (2009).

19. Delvigne, C., Cardinal, D., Hofmann, André L. Stratigraphic changes of Ge/Si, REE + Y and silicon isotopes as insights into the deposition of a Mesoarchean banded iron formation. Earth and Planetary Science Letters 355-356, 109-118 (2012).

20. Dimroth, E, Ifmreh, L, Goulet, N, and Rocheleau, M. Evolution of the south central segment of the Archean Abitibi Belt, Quebec Part 1 Stratigraphy and paleogeographic model. Canadian Journal of Earth Sciences, 19: 1729-1758 (1982).

21. Farber, K., Dziggel, A., Meyer, F.M., Prochaska, W., Hofmann, A., Harris, C. Fluid inclusion analysis of silicified Paleoarchean oceanic crust - A record of Archaean seawater? Precambrian Research 206: 150-164 (2015).

22. Fitoussi, C., Bourdon, B., Kleine, T., Oberli, F., Reynolds, B.C., Si isotope systematics of meteorites and terrestrial peridotites: implications for $\mathrm{Mg} / \mathrm{Si}$ fractionation in the solar nebula and for Si in the Earth's core. Earth and Planetary Science Letters, 287: 77-85 (2009).

23. Franklin, J.M., Gibson, H.L., Jonasson, I.R., and Galley, A.G. Volcanogenic massive sulfide Deposits: Economic Geology 100th Anniversary Volume: 523-560 (2005). 
24. Fyon, J.A., Cole, S., Geology of part of the Temagami greenstone belt, District of Nipissing, including relationships between lithological, alteration, and structural features and preciousmetal occurrences. In Summary of Field Work and Other Activities. Ontario Geological Survey, Misc. Pap. 146, pp. 108-115 (1989).

25. Galley and van Breemen, 2002 Galley, A.G. and Van Breemen, O., Timing of synvolcanic magmatism in relation to base-metal mineralization, Rouyn-Noranda, Abitibi volcanic belt, Quebec. Natural Resources Canada, Geological Survey of Canada. p.11 (2002).

26. Geilert, S., Vroon, P.Z., Roerdink, D.L., Van Cappellen, P., van Bergen, M.J. Silicon isotope fractionation during abiotic silica precipitation at low temperatures: Inferences from flowthrough experiments. Geochimica et Cosmochimica Acta 142, 95-114 (2014).

27. Geilert, S., Vroon, P.Z., Keller, N.S., Gudbrandsson, S., Stefansson, A., van Bergen, M.J. Silicon isotope fractionation during silica precipitation from hot-spring waters: Evidence from the Geysir geothermal field, Iceland. Geochimica et Cosmochimica Acta, 154, 403-427 (2015).

28. Gibson, H.L., and Watkinson, D.H. Volcanogenic massive sulfide deposits of the Noranda cauldron and shield volcano, Quebec: Canadian Institute of Mining and Metallurgy Special Volume 43: 119-132 (1990).

29. Gibson, H.L., Watkinson, D.H., Comba, C.D.A. Silicification: Hydrothermal Alteration in an Archean Geothermal System within the Amulet Rhyolite Formation, Noranda, Quebec. Economic Geology 78: 954-971 (1983).

30. Hannington, M.D., Santaguida, F., Kjarsgaard, I.M., Cathles, L.M., Regional-scale hydrothermal alteration in the Central Blake River Group, western Abitibi subprovince, Canada: implications for VMS prospectivity. Mineralium Deposita, 38: 393-422 (2003).

31. Hanor, J.S., Duchac, K.C., 1990. Isovolumetric silicification of Early Archean komatiites: Geochemical mass balances and constraints on origin. The Journal of Geology 98: 63-877 (1990).

32. Heck, P.R., Huberty, J.M., Kita, N.T., Ushikubo, T., Kozdon, R., Valley, J.W. SIMS analyses of silicon and oxygen isotope ratios for quartz from Archean and Paleoproterozoic banded iron formations. Geochimica et Cosmochimica Acta 75, 5879-5891 (2011).

33. Hopkinson, L., Roberts, S., Herrington, R., Wilkinson, J. Self-organization of submarine hydrothermal siliceous deposits: Evidence from the TAG hydrothermal mound, $26^{\circ} \mathrm{N}$ Mid-Atlantic Ridge. Geology 26, 347-350 (1999).

34. Houlé, M.G. Geological and mineral potential of McArthur Township in the Bartlet dome: Ontario Geological Survey Open File Report 6192: 6-1-6-14 (2006). 
35. Isley, A.E. Hydrothermal plumes and the Delivery of Iron to Banded Iron Formation. The Journal of Geology 103, 169-185 (1995).

36. Isley, A.E., and Abbott, D.H. Plume-related mafic volcanism and the deposition of banded iron formation. J. Geophys. Res. 104, 15461-15477 (1999).

37. Kimberley, M.M. Geochemical distinctions among environmental types of iron formations. Chemical Geology 25, 185-212 (1979).

38. King, E.M., Tucker Barrie, C. and Valley, J.W. Hydrothermal alteration of oxygen isotope ratios in quartz phenocrysts, Kidd Creek mine, Ontario: Magmatic values are preserved in zircon. Geology, 25(12), pp.1079-1082 (1997).

39. Kleine, B.I., Stefánsson, A., Halldórsson, S.A., Whitehouse, M.J. and Jónasson, K., Silicon and oxygen isotopes unravel quartz formation processes in the Icelandic crust. Geochemical Perspectives Letters 7, 5-11 (2018).

40. Konhauser, K.O., Planavsky, N.J., Hardisty, D.S., Robbins, L.J., Warchola, T.J., Haugaard, R., Lalonde, S.V., Partin, C.A., Oonk, P.B.H., Tsikos, H., Lyons, T.W., Bekker, A., Johnson, C.M. Iron formations: A global record of Neoarchaean to Paleoproterozoic environmental history. Earth-Science Reviews 172, 140-177 (2017).

41. Marin-Carbonne, J., Chaussidon, M., Robert, F. Micrometer-scale chemical and isotopic criteria (O and $\mathrm{Si}$ ) on the origin and history of Precambrian cherts: Implications for paleotemperature reconstructions. Geochimica et Cosmochimica Acta 92, 129-147 (2012).

42. Mueller, W. U., Mortensen, J. K. Age constraints and characteristics of subaqueous volcanic constructions, the Archean Hunter Mine Group, Abitibi greenstone belt. Precambrian Research 115: 119-152 (2002).

43. Mueller, W. U., Stix, J., Corcoran, P. L., Daigneault, R. Subaqueous calderas in the Archean Abitibi greenstone belt: An overview and new ideas. Ore Geology Reviews 35: 4-46 (2009).

44. Oelze, M., von Blanckenburg, F., Hoellen, D., Dietzel, M., Bouchez, J. Si stable isotope fractionation during adsorption and the competition between kinetic and equilibrium isotope fractionation: Implications for weathering systems. Chemical Geology 380, 161-171 (2014).

45. Oelze, M., von Blanckenburg, F., Bouchez, J., F., Hoellen, D., Dietzel. The effect of Al on Si isotope fractionation investigated by silica precipitation experiments, Chemical Geology 397 , 95-105 (2015).

46. Opfergelt, S., Cardinal, D., Andre, L., Delvigne, C., Bremond, L., Delvaux, B. Variations of $\delta^{30} \mathrm{Si}$ and $\mathrm{Ge} / \mathrm{Si}$ with weathering and biogenic input in tropical basaltic ash soils under monoculture. Geochimica et Cosmochimica Acta 74, 225-240 (2010). 
47. Otake, T., Wesolowski, D.J., Anovitz, L.M., Allard, L.F. and Ohmoto, H. Experimental evidence for non-redox transformations between magnetite and hematite under H2-rich hydrothermal conditions. Earth and Planetary Science Letters, 257(1-2), pp.60-70 (2007).

48. Pan, J. (thesis). A Geological and Geochemical Transect of the Volcanic Stratigraphy in the D'Alembert-Cléricy Area, Noranda, Québec. McGill University, 1-148 (1993).

49. Péloquin, A.S., Potvin, R., Paradis, S., Lafleche, M.R., Verpaelst, P., and Gibson, H.L., The Blake River Group, Rouyn-Noranda area, Quebec: A stratigraphic synthesis in the northwestern Quebec Polymetallic Belt. Canadian Institute of Mining and Metallurgy, Special volume 43: 107-118 (1990).

50. Piercey, S.J., Chaloux, E.C., Péloquin, A.S., Hamilton, M.A., Creaser, R.A. Synvolcanic and Younger Plutonic Rocks from the Blake River Group: Implications for Regional Metallogenesis. Economic Geology 103 (6): 1243-1268 (2008).

51. Pollington, A.D., Kozdon, R., Anovitz, L.M., Georg, R.B., Spicuzza, M.J. and Valley, J.W. Experimental calibration of silicon and oxygen isotope fractionations between quartz and water at $250 \mathrm{C}$ by in situ microanalysis of experimental products and application to zoned low $\delta 30$ Si quartz overgrowths. Chemical Geology, 421, pp.127-142 (2016).

52. Prentice, A., The effects of dissolution on the silicon and oxygen isotope compositions of silica phytoliths (2014).

53. Reeves, E.P., McDermott, J.M., Seewald, J.S. The origin of methane thiol in mid-ocean ridge hydrothermal fluids. PNAS 111: 5474-5479 (2014).

54. Rimstidt, J.D., Barnes, H.L. The kinetics of silica-water reactions. Geochimica et Cosmochimica Acta 44, 1683-1699 (1980).

55. Robert, F., Chaussidon, M., 2006. A paleotemperature curve for the Precambrian oceans based on silicon isotopes in chert. Nature 443: 969-972.

56. Savage, P.S., Georg, R.B., Armytage, R.M.G., Williams, H.M., Halliday, A.N. Silicon isotope homogeneity in the mantle. Earth and Planetary Science Letters 295, 139-146 (2010).

57. Snyder, D.B., Cary, P. and Salisbury, M. 2D-3C high-resolution seismic data from the Abitibi Greenstone Belt, Canada. Tectonophysics, 472(1-4), pp.226-237 (2009).

58. Steinhoefel, G., Horn, I., von Blanckenburg, F. Micro-scale tracing of Fe and Si isotope signatures in banded iron formation using femtosecond laser ablation. Geochimica et Cosmochimica Acta 73, 5343-5360 (2009).

59. Steinhoefel, G., von Blanckenburg, F., Horn, I., Konhauser, K.O., Beukes, N.J., Gutzmer, J. Deciphering formation processes of banded iron formations from the Transvaal and the 
Hamersley successions by combined $\mathrm{Si}$ and Fe isotope analysis using UV femtosecond laser ablation. Geochimica et Cosmochimica Acta 74, 2677-2696 (2010).

60. Taylor, H.P. and Epstein, S., Oxygen isotope studies of Ivory Coast tektites and impactite glass from the Bosumtwi Crater, Ghana. Science, 153(3732), pp.173-175 (1966).

61. Thurston, P.C., Ayer, J.A., Goutier, J., Hamilton, M.A. Depositional Gaps in Abitibi Greenstone Belt Stratigraphy: A Key to Exploration for Syngenetic Mineralization. Economic Geology 103: 1097 - 1134 (2008).

62. Thurston, P.C., Kamber, B.S. and Whitehouse, M. Archean cherts in banded iron formation: insight into Neoarchean ocean chemistry and depositional processes. Precambrian Research, 214, pp.227-257 (2012).

63. Van den Boorn, S. H. J. M., van Bergen, M. J., Nijman, W., Vroon, P. Z. Dual Role of seawater and hydrothermal fluids in Early Archean chert formation: Evidence from silicon isotopes. Geology 35, 939-942 (2007).

64. Van den Boorn, S.H.J.M., van Bergen, M.J., Vroon, P., de Vries, S.T., Nijman, W. Silicon isotope and trace element constraints on the origin of $\sim 3.5 \mathrm{Ga}$ cherts: Implications for Early Archaean marine environments. Geochimica et Cosmochimica Acta 74, 1077-1103 (2010).

65. Von Damm, K.L., Bischoff, J.L., Rosenbauer, R.J., Quartz solubility in hydrothermal seawater: an experimental study and equation desecribing quartz solubility for up to $0.5 \mathrm{M}$ $\mathrm{NaCl}$ solutions. American Journal of Science 291: 977-1007 (1991).

66. Yu, H.M., Li, Y.H., Gao, Y.J., Huang, J. and Huang, F. Silicon isotopic compositions of altered oceanic crust: Implications for Si isotope heterogeneity in the mantle. Chemical Geology, 479, pp.1-9 (2018). 
Table 1. Sample number, assemblage, rock type, and analysis performed (Brengman et al., 2020).

\begin{tabular}{|c|c|c|c|c|c|c|c|c|c|}
\hline & Sample \# & Assemblage & Rock type & Genetic group* & Petrography & Geochemistry & \begin{tabular}{|c|}
$\delta^{30} \mathrm{Si}_{\text {NBS }-28}$ \\
$\delta^{18} \mathrm{O}_{\mathrm{V} \text {-sMow }}$ \\
(IRMS) \\
\end{tabular} & $\begin{array}{c}\mathrm{\delta}^{30} \mathrm{Si}_{\text {NSS.28 }} \\
\text { (SIMS) }\end{array}$ & SIMS Target ${ }^{\star \star}$ \\
\hline & Temj & $>2750 \mathrm{Ma}$, Temagami & iron formation, oxide facies & (1) chem. sedimentary rock & $\mathrm{x}$ & $x$ & & $\mathrm{x}$ & micro-quartz \\
\hline & Temcf & $>2750 \mathrm{Ma}$, Temagami & iron formation, oxide facies & (1) chem. sedimentary rock & $\mathrm{x}$ & $x$ & $x$ & $\mathrm{x}$ & micro-quartz \\
\hline & Tem13Db & $>2750 \mathrm{Ma}$, Temagami & iron formation, oxide facies & (1) chem. sedimentary rock & $\mathrm{x}$ & $\mathrm{x}$ & & & \\
\hline & AB-13-63 & 2734 - $2724 \mathrm{Ma}$ Deloro Assemblage (middle) & fine-grained felsic volcanic rock & (2) silicified rock (low ) & $\mathrm{x}$ & $x$ & & & \\
\hline & AB-13-64 & 2734 - 2724 Ma Deloro Assemblage (middle) & iron formation, sulfide facies & (1) chem. sedimentary rock & $\mathrm{x}$ & $x$ & & & \\
\hline & AB-13-65 & 2734 - 2724 Ma Deloro Assemblage (middle) & iron formation, oxide facies & (1) chem. sedimentary rock & $\mathrm{x}$ & $x$ & $\mathrm{x}$ & & \\
\hline & AB-13-66 & 2734 - 2724 Ma Deloro Assemblage (middle) & silica-rich fine-grained volcanic rock & (2) silicified rock (low ) & $\mathrm{x}$ & $\mathrm{x}$ & & & \\
\hline & AB-13-68 & 2734 - $2724 \mathrm{Ma}$ Deloro Assemblage (middle) & iron formation, oxide facies & (1) chem. sedimentary rock & $x$ & $x$ & & & \\
\hline 10 & AB-13-70 & 2734 - $2724 \mathrm{Ma}$ Deloro Assemblage (middle) & iron formation, oxide facies & (1) chem. sedimentary rock & $\mathrm{x}$ & $\mathrm{x}$ & & x (2 samples) & micro-quartz \\
\hline 11 & AB-13-71 & 2734 - $2724 \mathrm{Ma}$ Deloro Assemblage (middle) & mixed volcanic and chem sed (debris flow) & (3) mixed volc. chem. rock & $x$ & $x$ & & & \\
\hline 12 & AB-13-72 & 2734 - 2724 Ma Deloro Assemblage (upper) & iron formation, oxide facies & $(1,2)$ silicified chem. sed. & $x$ & $x$ & $x$ & $\times(2$ samples $)$ & mega-quartz \\
\hline 13 & AB-13-73 & 2734 - $2724 \mathrm{Ma}$ Deloro Assemblage (upper) & iron formation, oxide facies & $(1,2)$ silicified chem. sed. & $\mathrm{x}$ & $\mathrm{x}$ & & & \\
\hline 14 & AB-13-74 & 2734 - 2724 Ma Deloro Assemblage (upper) & iron formation, oxide facies & $(1,2)$ silicified chem. sed. & $\mathrm{x}$ & $\mathrm{x}$ & & $\mathrm{x}$ & micro-quartz \\
\hline 15 & AB-13-76 & 2734 - 2724 Ma Deloro Assemblage (upper) & iron formation (fragmented), oxide facies & (3) mixed volc. chem. rock & $\mathrm{x}$ & $\mathrm{x}$ & & $x$ & \\
\hline 16 & AB-11-11 & - 2722 Ma Hunter Mine Group & silicified felsic volcanic rock & (2) silicified rock (low ) & $\mathrm{x}$ & $\mathrm{x}$ & $\mathrm{x}$ & $\mathrm{x}$ & $\begin{array}{l}\text { micro-quartz, quartz } \\
\text { phenocrysts }\end{array}$ \\
\hline 17 & AB-11-12 & - 2722 Ma Hunter Mine Group & silicified felsic volcanic rock & (2) silicified rock (low ) & $\mathrm{x}$ & $\mathrm{x}$ & $x$ & $\mathrm{x}$ & micro-quartz \\
\hline 15 & AB-11-19 & - 2722 Ma Hunter Mine Group & silicified felsic volcanic rock & (2) silicified rock (high) & $x$ & $x$ & $\mathrm{x}$ & & \\
\hline 20 & AB-11-25 & -2722 Ma Hunter Mine Group & silicified felsic volcanic rock & (2) silicified rock (high) & $\mathrm{x}$ & $\mathrm{x}$ & $x$ & & \\
\hline 21 & Am. Basalt & 2698 - 2696 Ma Blake River Group & silicified basalt $\mathrm{w}$ / quartz-filled amygdules & (2) silicified rock (low ) & $\mathrm{x}$ & $x$ & & $x$ (AMYG) & mega-quartz \\
\hline 22 & AB-13-08 & 2698 - 2696 Ma Blake River Group & silicified basalt $\mathrm{w}$ / quartz-filled amygdules & (2) silicified rock (low ) & $x$ & $x$ & & & \\
\hline 23 & AB-13-10 & 2698 - $2696 \mathrm{Ma}$ Blake River Group & silicified basalt w/ quartz-filled amygdules & (2) silicified rock (low) & $\mathrm{x}$ & $x$ & & & \\
\hline 24 & AB-13-11 & 2698 - 2696 Ma Blake River Group & silicified basalt w / quartz-filled amygdules & (2) silicified rock (low) & $\mathrm{x}$ & $x$ & & & \\
\hline 25 & AB-13-12 & 2698 - 2696 Ma Blake River Group & Si-rich exhalite (overlying the basalt) & (3) mixed volc. chem. rock & $\mathrm{x}$ & $x$ & & $x(A B-13-09)$ & micro-quartz \\
\hline 26 & AB-13-13 & 2698 - 2696 Ma Blake River Group & Silicified andesite (Amulet "rhyolite") & (2) silicified rock (med) & $x$ & $x$ & & $x$ & mega-quartz \\
\hline 27 & AB-13-14 & 2698 - 2696 Ma Blake River Group & Silicified andesite (Amulet "rhyolite") & (2) silicified rock (med) & $\mathrm{x}$ & $\mathrm{x}$ & & & \\
\hline $2 \varepsilon$ & AB-13-15 & 2698 - 2696 Ma Blake River Group & Silicified andesite (Amulet "rhyolite") & (2) silicified rock (med) & $\mathrm{x}$ & $\mathrm{x}$ & & & \\
\hline 25 & AB-13-16 & 2698 - 2696 Ma Blake River Group & Silicified andesite (Amulet "rhyolite") & (2) silicified rock (med) & $\mathrm{x}$ & $x$ & & $x$ & mega-quartz \\
\hline 30 & AB-13-17 & 2698 - 2696 Ma Blake River Group & Silicified andesite (Amulet "rhyolite") & (2) silicified rock (med) & $\mathrm{x}$ & $x$ & & $x$ & mega-quartz \\
\hline 31 & AB-13-18 & 2698 - $2696 \mathrm{Ma}$ Blake River Group & Silicified andesite (Amulet "rhyolite") & (2) silicified rock (med) & $\mathrm{x}$ & $\mathrm{x}$ & & & \\
\hline 32 & AB-13-20 & 2698 - 2696 Ma Blake River Group & Silicified andesite (Amulet "rhyolite") & (2) silicified rock (med) & $\mathrm{x}$ & $\mathrm{x}$ & & & \\
\hline
\end{tabular}

\section{${ }^{*}$ Genetic Group information}

(1) chem. sedimentary rock: rock with a demonstrable chemical sedimentary origin based on field context, confirmed with petrography

(2) silicified rock (low, med, high): rock with demonstrable silica mobility in the form of silicification, low, medium, and high descriptions are qualitative assessments of the relative amount Si mobility compared to the rest of the sample suite (3) mixed volc. chem. rock: rocks with both volcanic and chemical sedimentary features, e.g. heterolithic volcaniclastic rocks interpreted as debris flows, fragmented iron formation with volcanic material in between fragments, and exhalites *SIM S Target information: micro-quartz and mega-quartz defined based definitions and crystal sizes in Boggs, 2001

21 This is a pre-print that has not yet undergone peer review.

We submitted the manuscript for publication in a peer reviewed journal. 


\section{Constraining mechanisms of quartz precipitation during silicification and chemical sedimentation in the in the 2.7 Ga Abitibi Greenstone Belt, Canada}

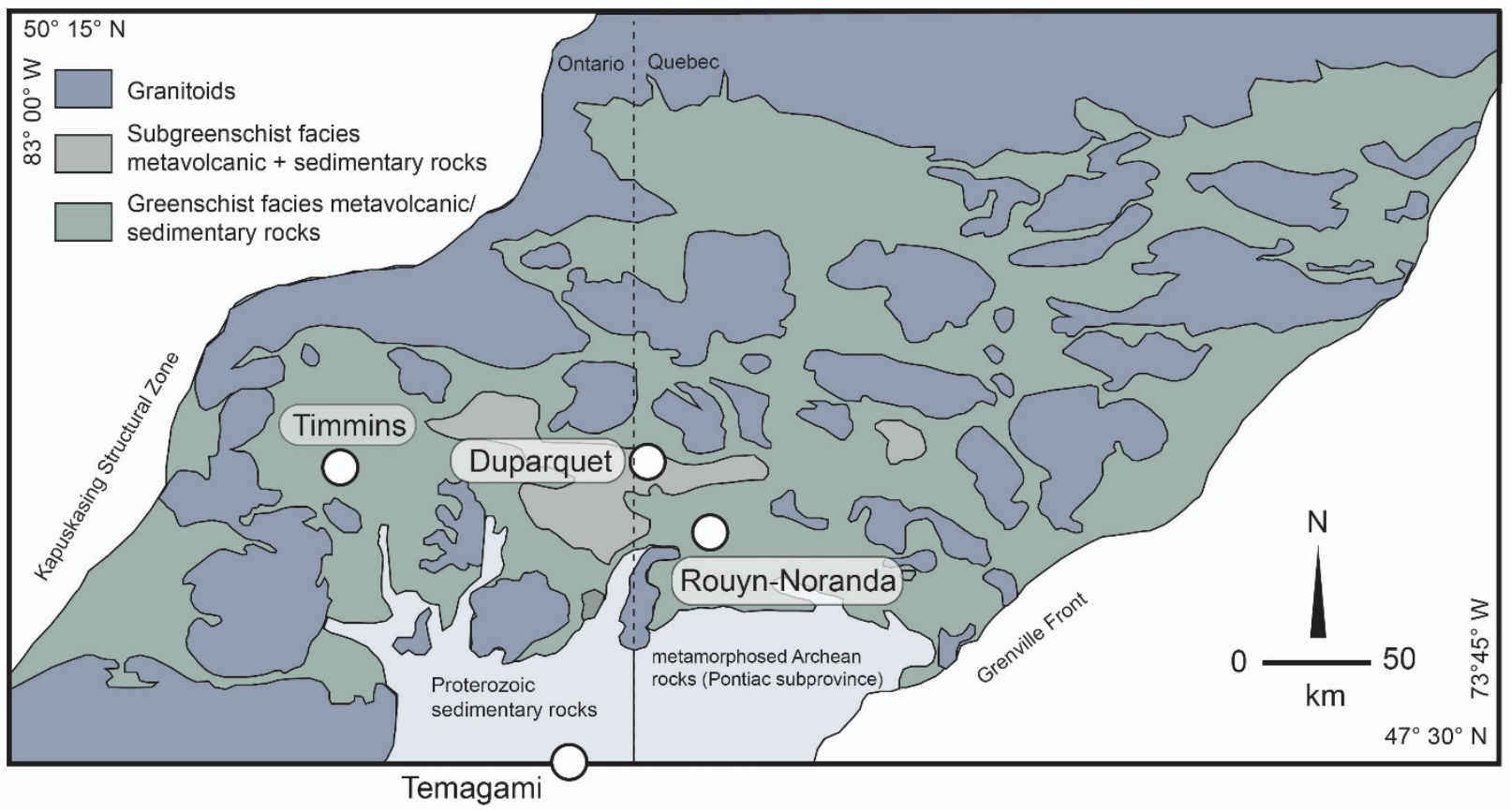

Figure 1. Schematic geologic map of volcano-sedimentary assemblages that form part of the $\sim 2.7$ Ga Abitibi Greenstone Belt, Canada based on the work of Ayer et al. (2005), Thurston et al., (2008), and Hannington et al., (2003). Circle symbols denote important towns that link to sample localities described in the text. 

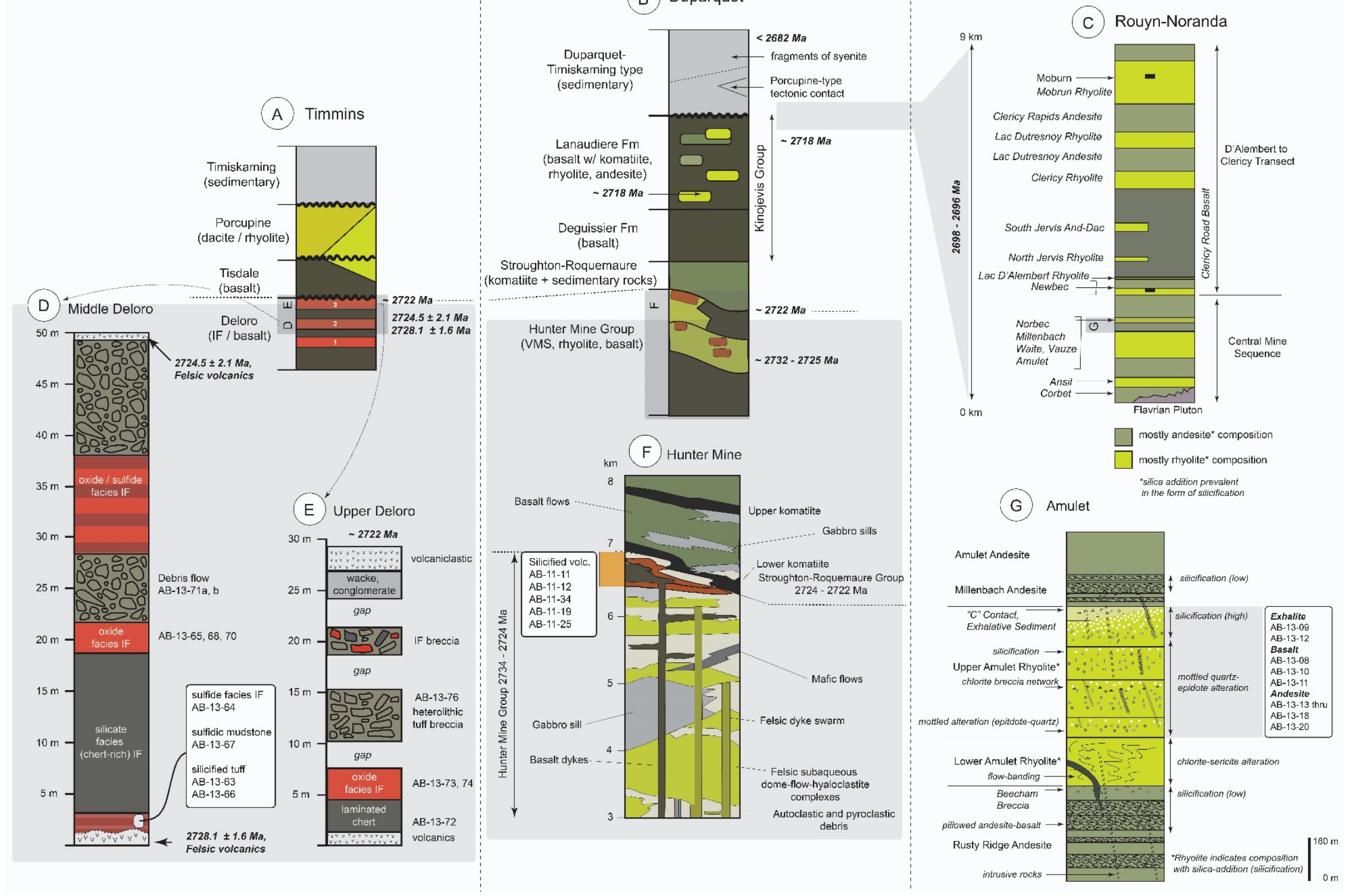
Figure 2. Cartoon stratigraphic columns from sample localities near Timmins, ON (A, D, E), Duparquet, QC (B, F), and Rouyn-Noranda, QC (C, G). Columns A and B are after Thurston et al., (2008), C is after Pan (1993), D is after Baldwin (2011), E is after Thurston et al., (2008; and 2012), $\mathrm{F}$ is after Brengman and Fedo (2018), and $\mathrm{G}$ is after Gibson et al. (1983). 
$>2750$ Ma Temagami

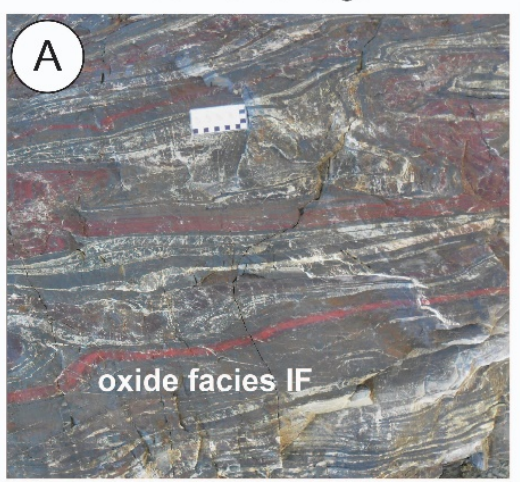

$\sim 2724.5 \pm 2.1$ - $2722 \mathrm{Ma}$ Upper Deloro

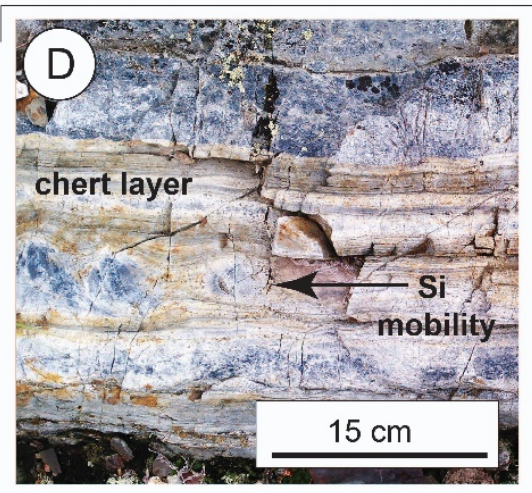

$2728.1 \pm 1.6 \mathrm{Ma}-2724.5 \pm 2.1 \mathrm{Ma}$ Middle Deloro
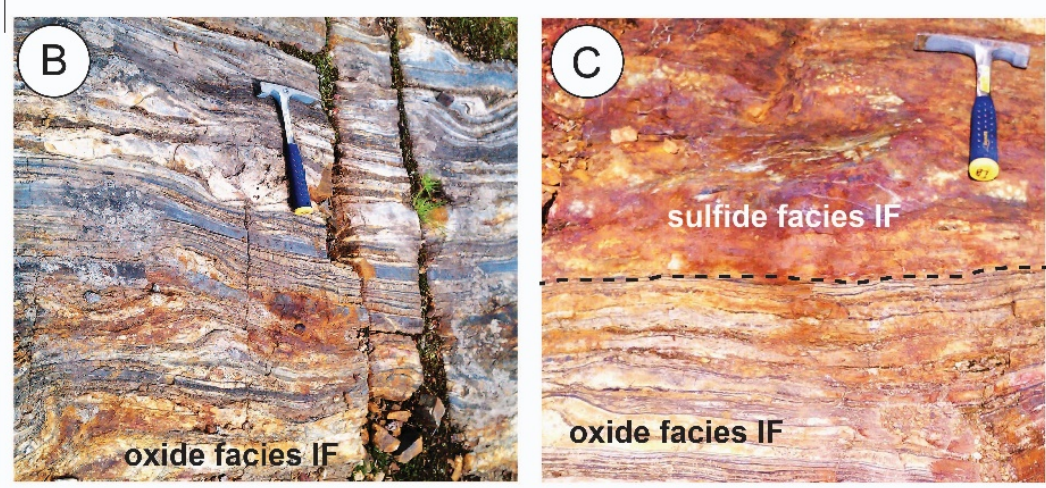

2698 - 2696 Ma Blake River Group
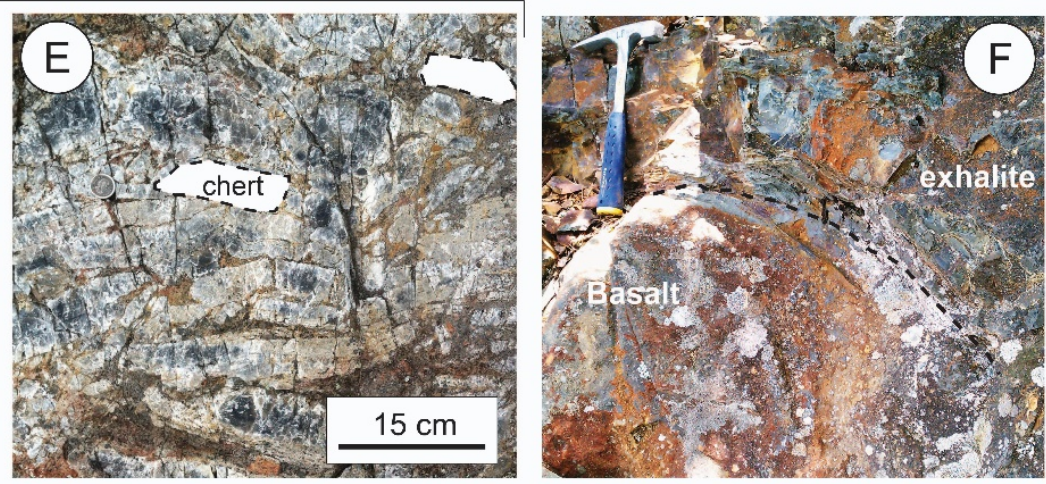

Figure 3. Representative field outcrop photos from localities in this study. (a) Oxide "facies" iron formation near Temagami, ON. Scale card represents $10 \mathrm{~cm}$ length. (B) Oxide "facies" iron formation from the Middle Deloro unit near Timmins, ON. Rock hammer for scale. (C) Sulfide "facies" iron formation in contact with oxide "facies" iron formation from the Middle Deloro unit near Timmins, ON. (D) Visible silica mobility (silicification) within a chert layer in oxide facies iron formation from the Upper Deloro unit near Timmins, ON. (E) Chert fragments which appear silicified (note coloration differences between rims and cores of clasts) within an oxide iron formation from the Upper Deloro unit near Timmins, ON. (f) Exhalitive, silica-rich precipitate draping pillowed basalt in the Upper Amulet Member of the Blake River Formation near Noranda, QC. Rock hammer for scale. 

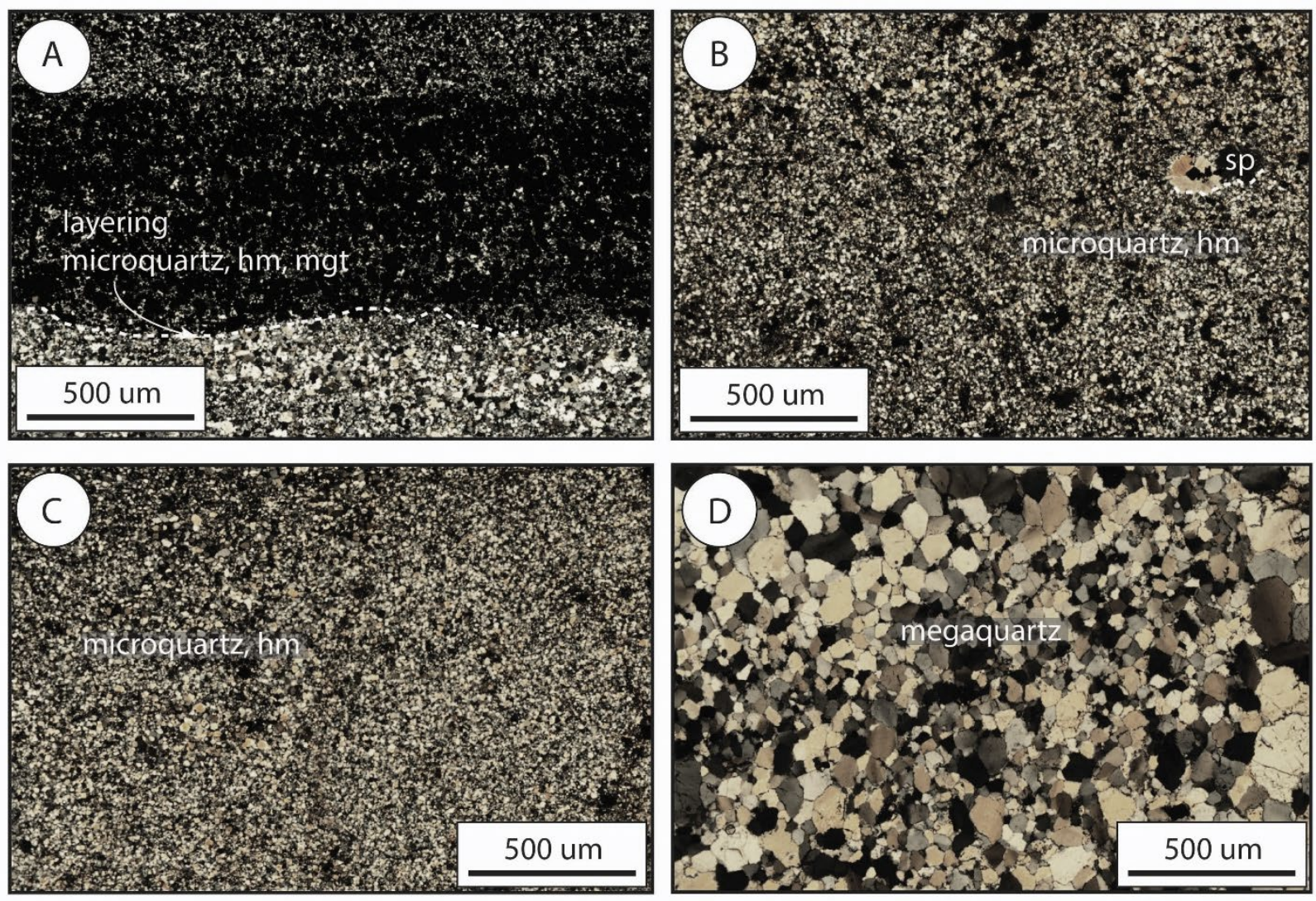

Figure 4. Photomicrographs of representative iron formation samples. (A) Cross-polarized light image of iron formation sample TEMcf from near Temagami, ON. Microquartz (microqtz), hematite (hm), and magnetite (mgt) are the dominant mineral phases. (B) Cross-polarized light image of chert sample AB-13-70 from the Middle Deloro Iron formation near Timmins, ON. Microquartz dominates the mineral assemblage. Spherules of putative diagenetic or volcanic origin are present and highlighted. (C) Cross-polarized light image showing microquartz and hematite within iron formation fragment (sample AB-13-76). (D) Cross-polarized light image showing mega-quartz from sample AB-13-72 of the Upper Deloro Iron formation near Timmins, ON. 

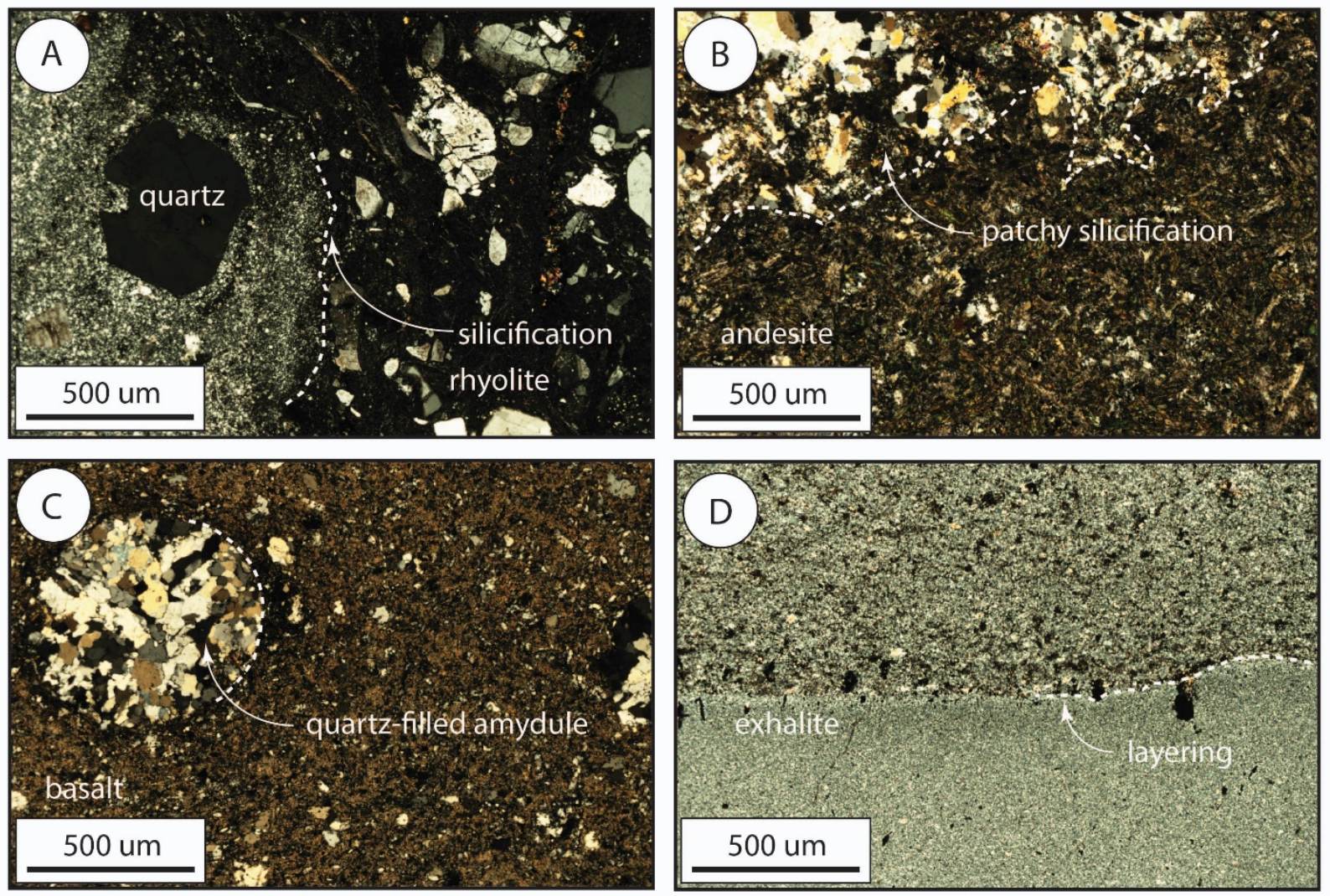

Figure 5. Photomicrographs of representative silicified volcanic rock samples. (A) Cross-polarized light image of silicification patch within sample AB-11-11 from the Hunter Mine Group. Note volcanic phenocrysts (quartz) present within and external to areas of silicification. (B) Crosspolarized light image of patchy/ mottled silicification within Amulet member of the Blake River Group (sample AB-13-16). (C) Cross-polarized light image of amygdaloidal basalt sample AMYG from near Rouyn-Noranda, QC. Quartz and (qtz-filled amyg) chalcopyrite fill all amygdules. (D) Exhalite sample AB-13-09, which drapes the pillowed basalt unit (C). Microquartz is the dominant mineral phase and crystal size varies by layer. 

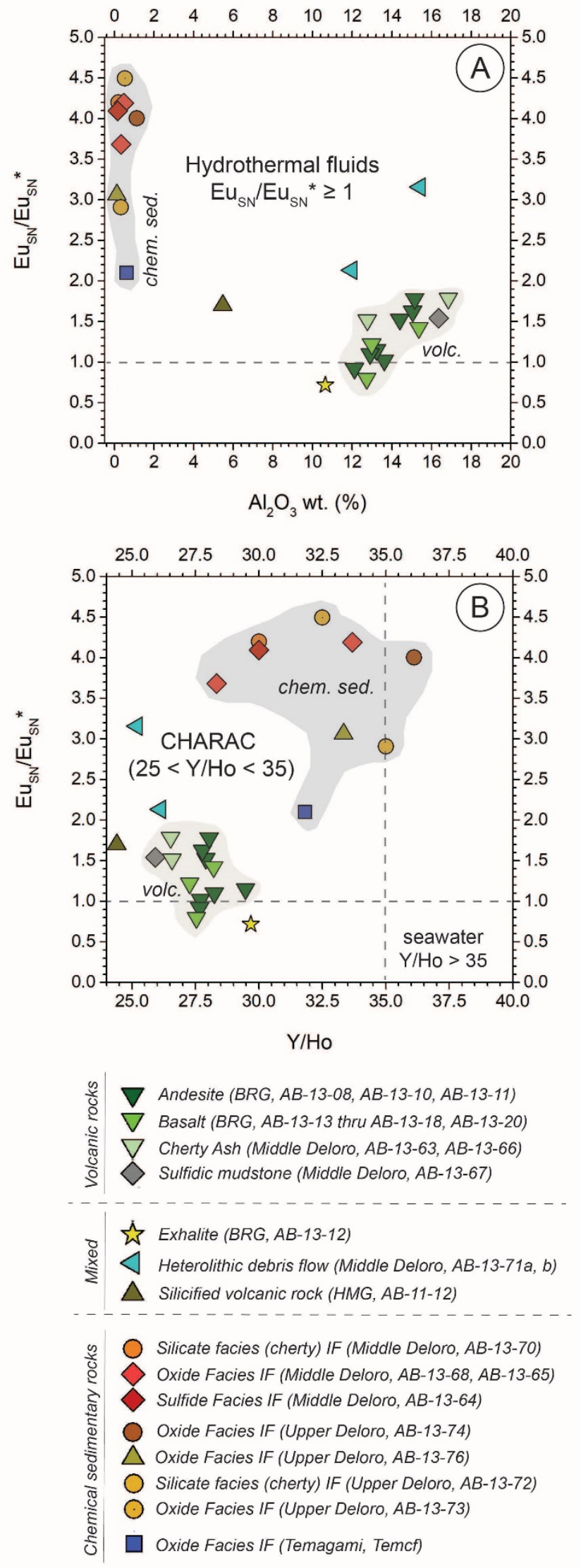

28 This is a pre-print that has not yet undergone peer review.

We submitted the manuscript for publication in a peer reviewed journal. 
Figure 6. Representative geochemical plots for silicified volcanic rocks, chemical sedimentary rocks, and those of a mixed origin (e.g. IF breccia in a volcanic matrix) from the Blake River Group and Deloro Assemblage. (A) Europium anomaly ( $\mathrm{EusN}_{\mathrm{SN}} / \mathrm{Eu}^{*}{ }_{\mathrm{SN}}$ ) versus $\mathrm{Al}_{2} \mathrm{O}_{3}$ content. Note the clear delineation between chemical sedimentary rocks and volcanic rocks. Also important is the inheritance of a positive Europium anomaly in volcanic rocks, typically associated with hydrothermal fluid interaction. (B) Europium anomaly $\left(\mathrm{Eu}_{\mathrm{SN}} / \mathrm{Eu}^{*}{ }_{\mathrm{SN}}\right)$ versus $\mathrm{Y} / \mathrm{Ho}$ content. Note that most samples (including chemical sedimentary rocks and volcanic rocks) fall within the CHARAC field $(25<\mathrm{Y} / \mathrm{Ho}<35)$. Only sample AB-13-72 and AB-13-74 fall within the "seawater" field with respect to $\mathrm{Y} / \mathrm{Ho}$ values. 


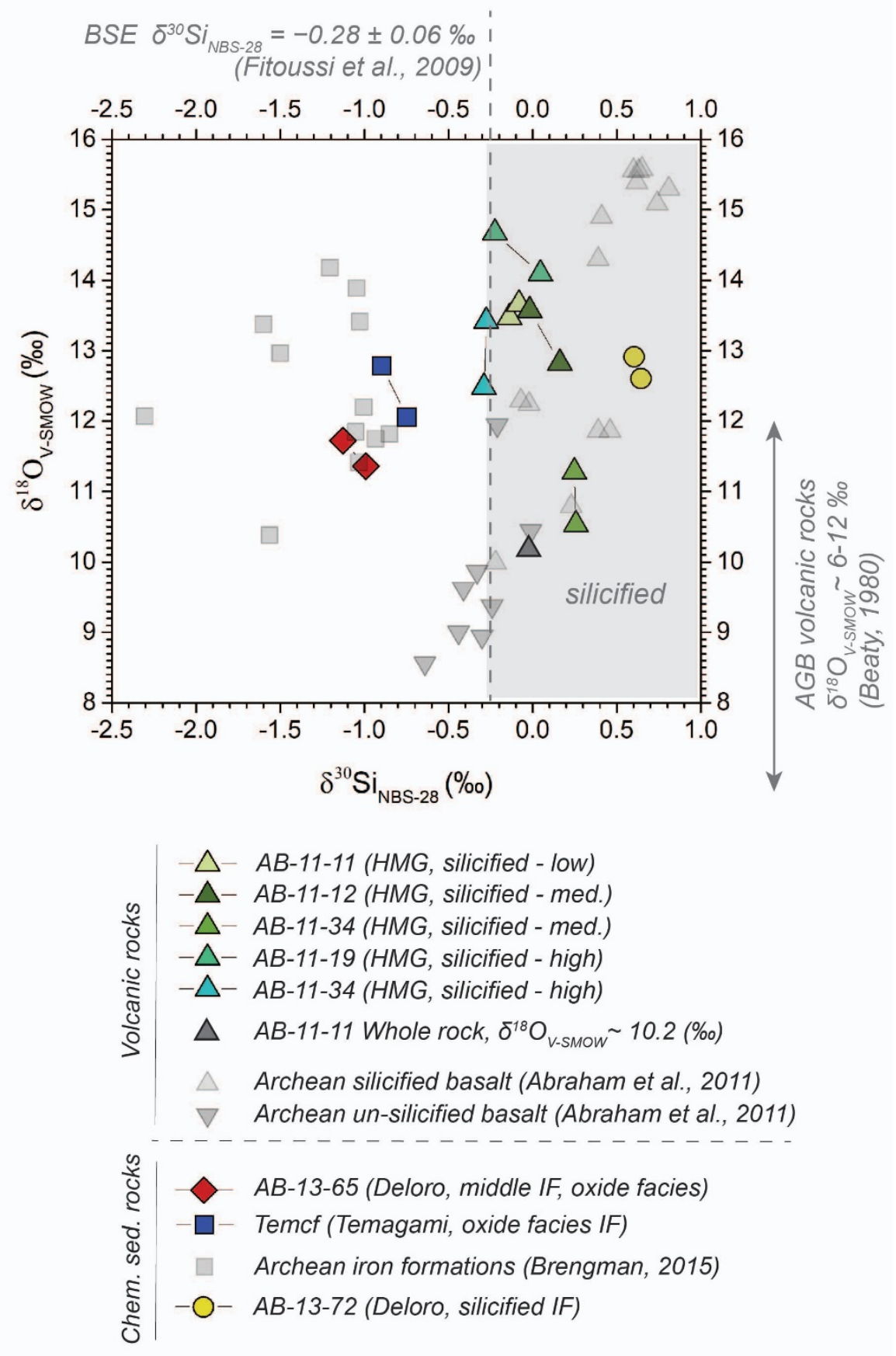

30 This is a pre-print that has not yet undergone peer review.

We submitted the manuscript for publication in a peer reviewed journal. 
Figure 7. Silicon and oxygen isotope data measured using IRMS of quartz mineral separates for select samples (AB-11-11 WR represents the whole rock value for sample AB-11-11). Lines connecting symbols represent duplicates. Analytical error reported is smaller than symbol size. Dashed line represents bulk silicate earth (BSE) values for silicon isotopes based on Fitoussi et al., (2008). Note that the whole rock value for AB-11-11 WR differs from the quartz separate for the same sample AB-11-11. We also include silicon and oxygen isotope values of silicified and unsilicified Archean basalt (Abraham et al., 2011) and Archean iron formations from greenstone belt terranes (Brengman, 2015) for comparison. Note the apparent separation between data for different rock types. 


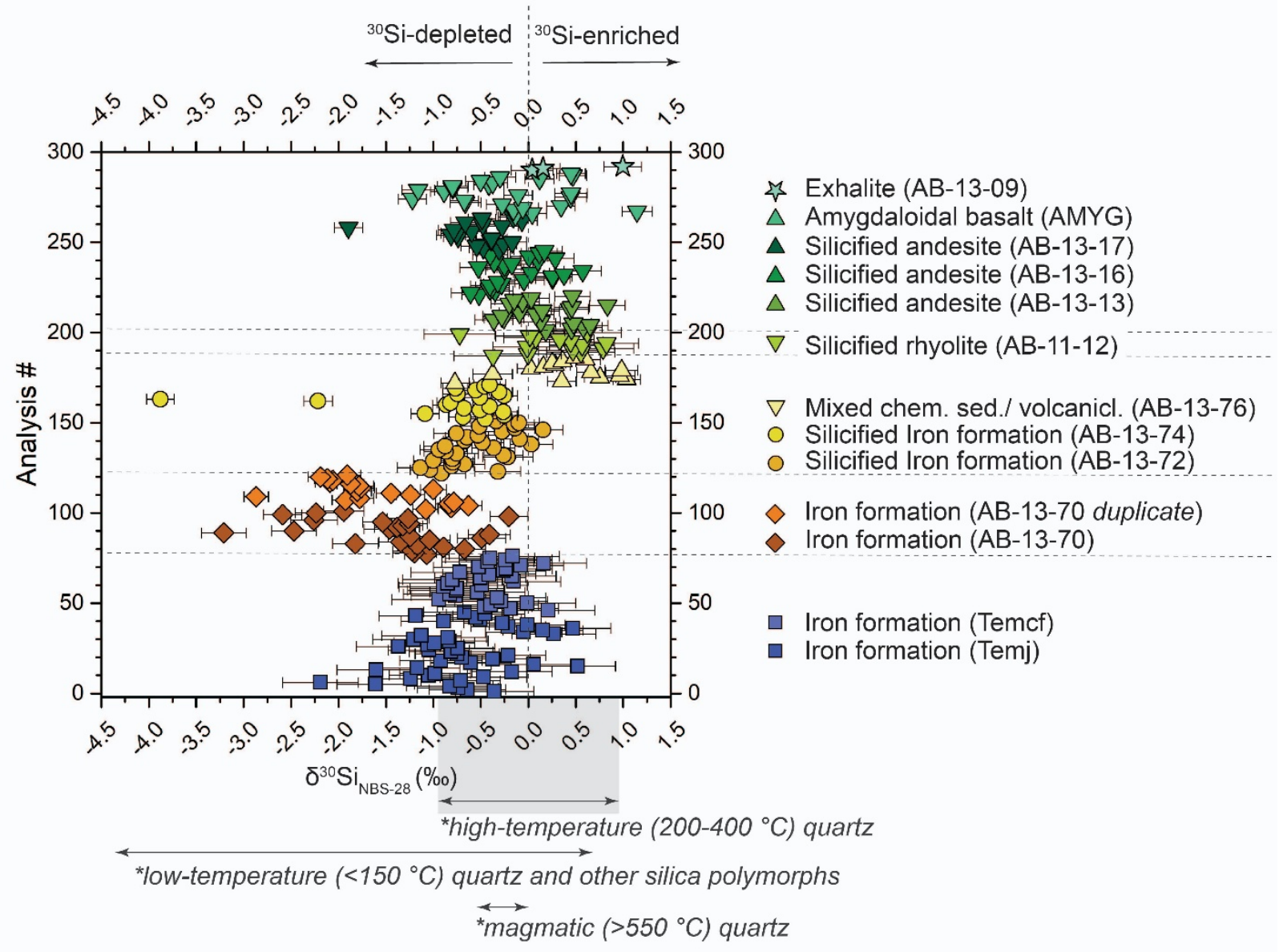

Figure 8. Silicon isotope values (obtained using SIMS; error bars represent $1 \sigma$ ) of single quartz crystals from select samples. $\mathrm{Y}$ axis represents point number, $\mathrm{x}$ axis represents silicon isotope value compared to NBS-28. Samples TEMj and TEM cf are from the pre-2750 Assemblage, samples AB-13-76, AB-13-74, AB-13-70 (1), AB-13-70 (2), AB-13-72 (1), and AB-13-72 (2) are from the Deloro Assemblage near Timmins, ON, sample AB-11-12 is from the Deloro Assemblage near Duparquet, QC, and samples AB-13-13, AB-13-16, AB-13-17, AMYG, and AB-13-09 are from the Blake River Assemblage near Rouyn-Noranda, QC. Range of values for low-temperature quartz $\left(<150{ }^{\circ} \mathrm{C}\right)$ and other silica polymorphs from modern icelandic samples (Kleine et al., 2018) plotted for reference. Range of values for high-temperature quartz $\left(<200-400{ }^{\circ} \mathrm{C}\right)$ and magmatic quartz $\left(>550^{\circ} \mathrm{C}\right)$ from modern icelandic samples (Kleine et al., 2018) plotted for reference. 

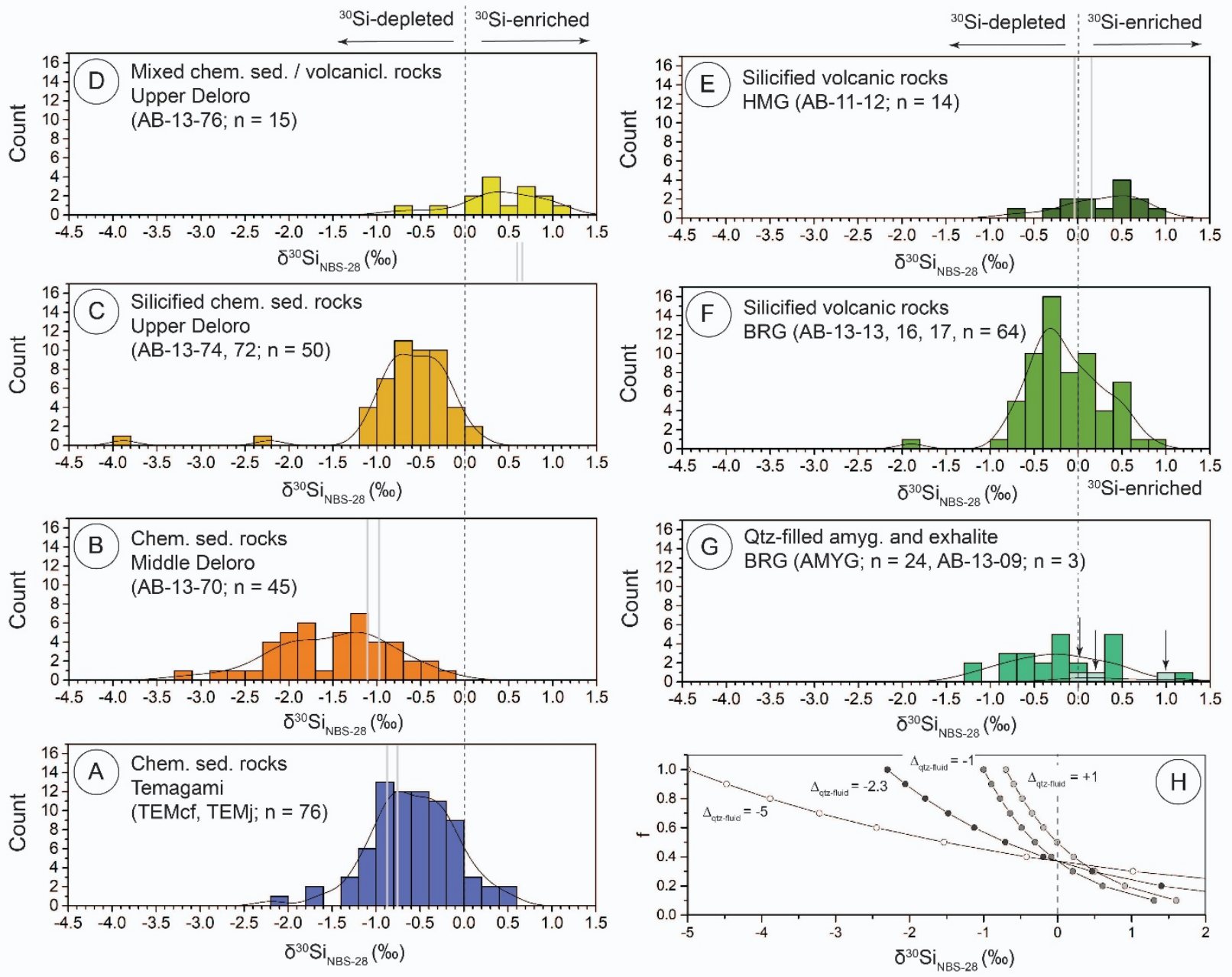

Figure 9. Silicon isotope values (obtained using SIMS; error bars represent $1 \sigma$ ) of single quartz crystals from select samples. Histograms include all in situ data from the present study. Y-axis represents silicon isotope value compared to international standard NBS-28, $\mathrm{x}$-axis represents count and kernel density distribution for each group. Samples are divided based on rock type for comparison, the dashed line represents a silicon isotope value of 0 per mil. Light colored lines represent silicon isotope values measured using IRMS for the same sample (plotted in Figure 7, values reported in Table S2). (A-G) Histograms for samples grouped based on rock type from the Deloro Assemblage, Hunter Mine Group, and Blake River Group. Rock types and SIMS targets are listed in Table 1, SIMS silicon isotope data is listed in Table S3 (summary of corrected values), and Table S4 (raw instrument data). (H) Calculated Rayleigh Distillation model for various fractionation factors. 


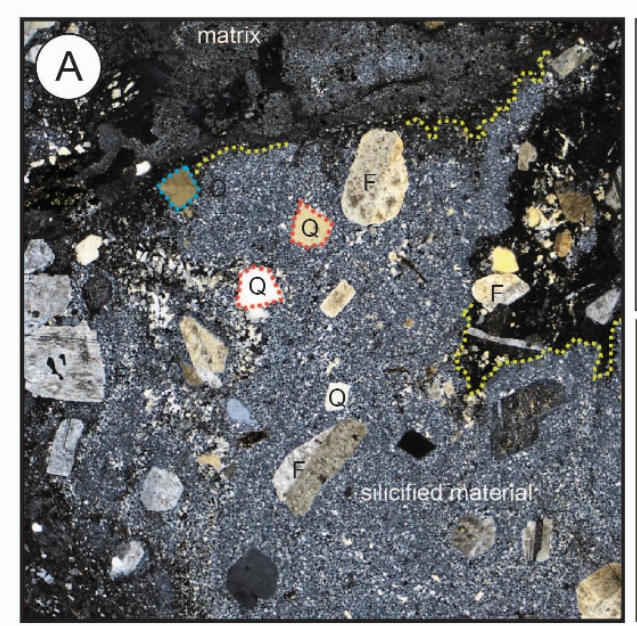

AB-11-11 Silicified volcanic rock

$10 \mathrm{~mm}$

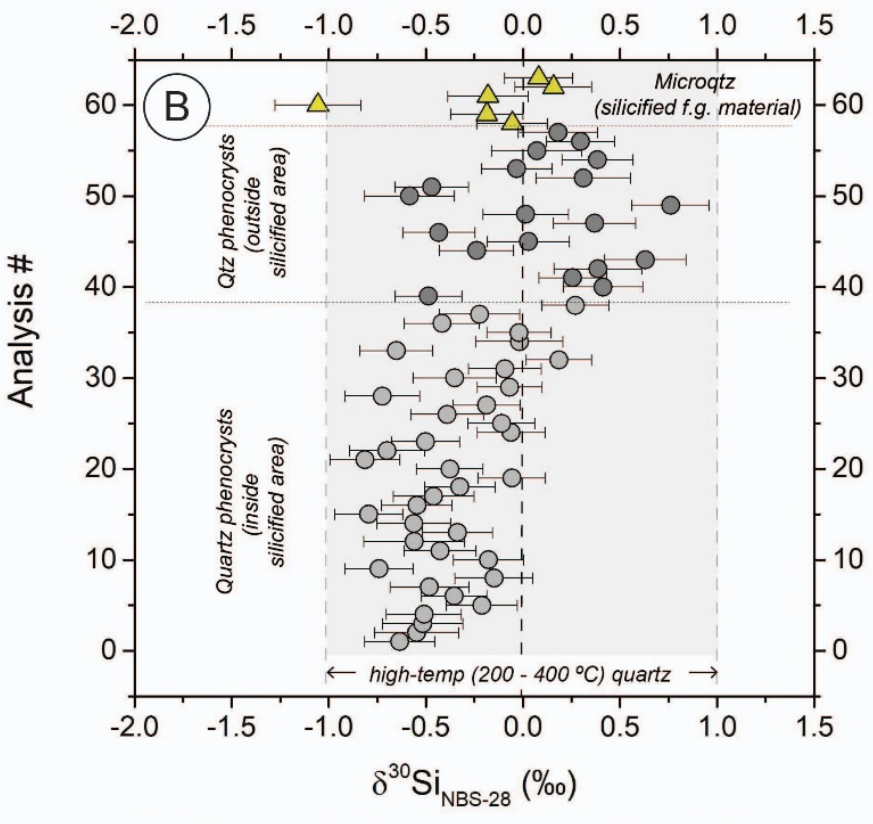

$\triangle$ Microquartz (silicified f.g. volcanic matrix material)

○ Quartz phenocrysts inside silicified f.g. volcanic material

- Quartz phenocrysts outside silicified f.g. volcanic material

Figure 10. Silicon isotope data measured using SIMS for silicified volcanic rock sample AB-1111. (A) Cross-polarized light composite image showing volcanic phenocrysts (quartz Q, feldspar F) inside and external to fine-grained, silicification patched which consist predominantly of microquartz. (B) Individual point analyses of quartz phenocrysts and associated silicified material from sample AB-11-11. Measurements include quartz phenocrysts inside silicified areas and external to them, as well as micro-quartz and mega-quartz associated with silicification (yellow triangles). 


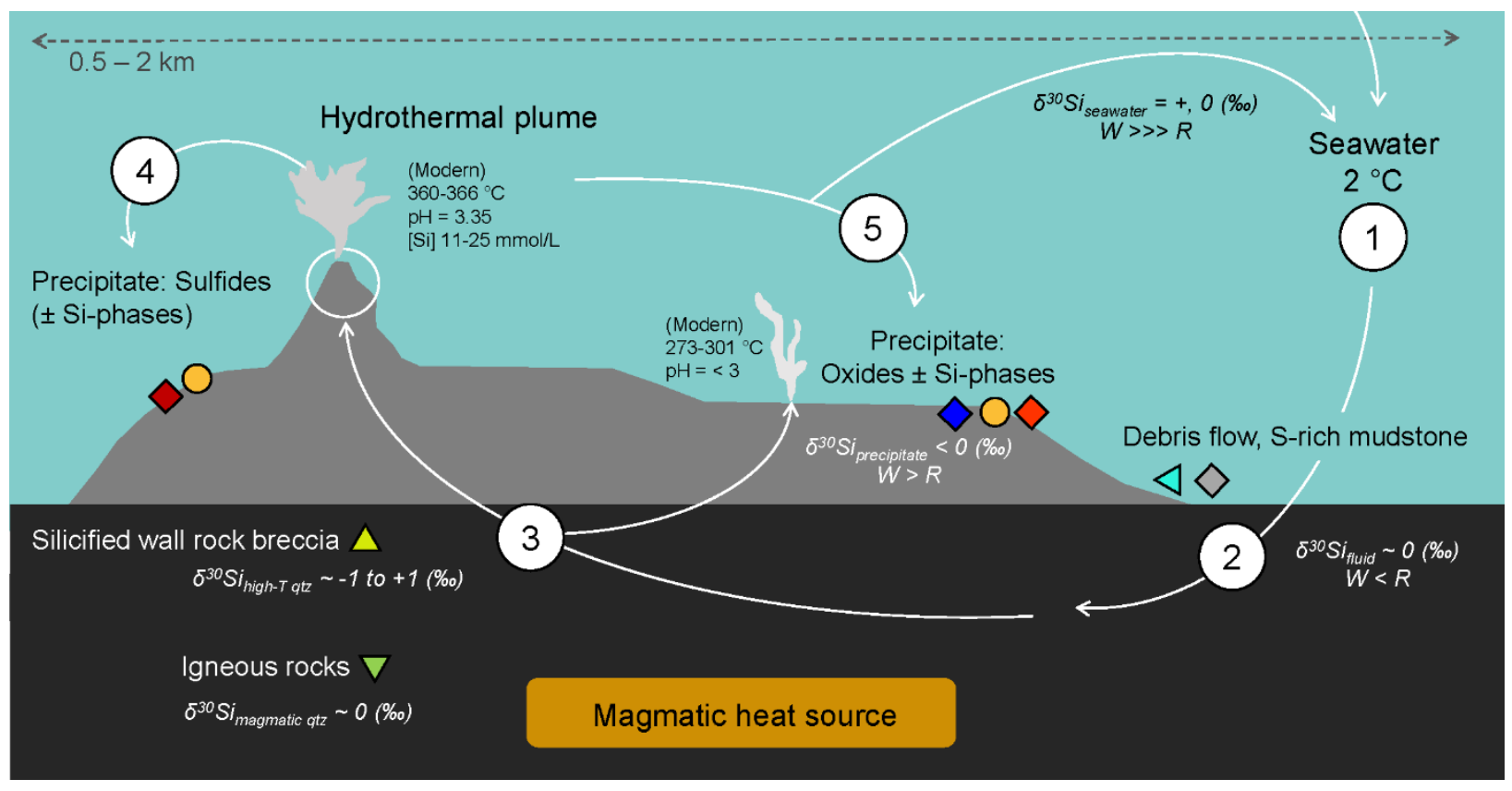

Figure 11. Idealized schematic representation of a depositional system and fluid evolution for the Deloro assemblage chemical sedimentary rocks and silicified rocks. Profile, geochemical parameters, and mineral distributions designed after TAG modern hydrothermal mound Hopkinson (1999). Temperature and $\mathrm{pH}$ of fluids can vary across modern hydrothermal mound, resulting in precipitation of different minerals (iron oxides vs. sulfides). Debris flow and S-rich mudstone represent locally derived volcanic and volcaniclastic material flanking the main depositional locus for hydrothermal minerals. Silicification occurs at depth and throughout the precipitated mineral assemblage similar to other VMS-type systems. Cold seawater infiltrates sediment and volcanic rock pile (1) leading to water: rock interaction (2) and subsequent silicification and associated volume changes (ie - potential brecciation (3)). Heated by the underlying magmatic body, fluid is expelled from the system through the hydrothermal pile (4). Upon contact with cold seawater, forced precipitation can occur depending on $\mathrm{pH}$ and solubility differences (5). As the fluid travels through the system (1-4), the water:rock ratio changes, as well as the potential geochemical signature. 